\title{
ZARAZ PO WOJNIE: Z HISTORII BADAŃ NAD POGRANICZEM POLSKO-RUSKIM W LATACH 1945-1956 (ZE SZCZEGÓLNYM UWZGLĘDNIENIEM GRODÓW CZERWIEŃSKICH)
}

\author{
RIGHT AFTER THE WAR: ON THE HISTORY OF STUDIES \\ ON THE POLISH-EARLY RUS' BORDERLAND CONDUCTED IN 1945-1956 \\ (WITH EMPHASIS ON SO-CALLED CHERVEN' TOWNS)
}

\begin{abstract}
The subject of this article is the history of studies on the Polish-early Rus' borderland, mainly so-called Cherven' Towns, i.e. the strongholds of Czermno and Gródek in eastern Poland. I focus on the post-war period (until 1956), but in order to present the events of that time in the proper context it is necessary to briefly go back in time to the Second Republic of Poland and the years 1939-1945. The origins of interest in a systematic analysis of the Cherven' Towns region can be tracked back to Lwów/L'viv in the 1930s. World War II thwarted the plans and goals made at that time. After 1945, studies on the gords in Czermno and Gródek were restarted and from 1952 excavations on this territory were carried out - officially - as part of Polish-Soviet cooperation. The excavations were abandoned in rather unclear circumstances. The article shows how the dramatic changes in Europe in the mid- $20^{\text {th }}$ century influenced the attitudes of scholars, including archaeologists, at that time.
\end{abstract}

KEY WORDS: archaeology, Middle Ages, Poland, Kiev Rus', Ukraine, Russia, Soviet Union, Cherven’ Towns, Czermno, Gródek, history of archaeology

\section{WPROWADZENIE}

W dorobku Czesława Miłosza (1911-2004) znajdujemy m.in. tom pt. Zaraz po wojnie. Korespondencja z pisarzami 1945-1950, będący zapisem listownych dyskusji poety z jego znajomymi, przyjaciółmi z czasów, gdy był on pracownikiem placówek dyplomatycznych (komunistycznej) Warszawy w Stanach Zjednoczonych (por. Miłosz 2007; na temat Miłosza w tym okresie zob. Franaszek 2011, 371-457)1. Do kręgu znajomych Miłosza należał

\footnotetext{
1 Artykuł przygotowano w ramach realizacji projektu badawczego pt. Złote jabłko polskiej archeologii. Zespo-
}

m.in. Tadeusz Juliusz Kroński (1907-1958), filozof-marksista, słynny Tygrys z Rodzinnej Europy (por. Miłosz 1959, 214-246; zob. też Zemła 2011). W jednym z listów (Warszawa, 28 VI 1946 r.) pisanych przez matkę filozofa - Zofię Krońską (1881-

by grodowe w Czermnie i Gródku (Grody Czerwieńskie) - chronologia i funkcja w świetle badań dawnych oraz weryfikacyjnych, finansowanego w ramach programu Ministra Nauki i Szkolnictwa Wyższego pod nazwą Narodowy Program Rozwoju Humanistyki (projekt nr 12H 120064 81).

Niniejszy tekst nie powstałby, gdyby nie pomoc całej grupy osób. Informacje na temat Zofii Wartołowskiej i jej 
1952) - czytamy m.in. "Ja mam się dobrze, tylko teraz jestem bardzo samotna, bo Zosia pojechała na wykopaliska do Sąsiadki w Lubelskie na dwa miesiące" (Miłosz 2007, 272).

Wspomniana Zosia to oczywiście Zofia Wartołowska (1911-1976), archeolog z Uniwersytetu Warszawskiego, znana przede wszystkim jako badaczka grodziska w Sąsiadce-Sutjejsku, często uznawanego za jeden z Grodów Czerwieńskich, gdzie - najpierw pod opieką Włodzimierza Antoniewicza (1893-1973), a następnie samodzielnie prowadziła zakrojone na szeroką skalę prace wykopaliskowe (1936-1939, 1945-1947, 1949-1959; por. Wartołowska 1958; zob. ostatnio Kalaga [red.] 2013) ${ }^{2}$.

O ile wiem, powyższy cytat to jedyny wkład naszego noblisty w studia nad historią polskiej archeologii.

W niniejszym szkicu ${ }^{3}$ chciałbym przedstawić kilka uwag na temat historii badań pogranicza polsko-ruskiego w okresie powojennym (do 1956). Naukowcy, w tym archeolodzy nie żyją rzecz jasna w wieży z kości słoniowej, tak więc wojna i jej

rodziny, a także zgodę na publikację listu Lewko Czykałenko do Wartołowskiej z dnia 16-go VIII 1940 (por. niżej) zawdzięczam jej bratanicy - Pani Jolancie Świdrowskiej de domo Wartołowskiej, której jeszcze raz bardzo serdecznie dziękuję za okazaną życzliwość. Za pomoc w nawiązaniu kontaktu z Panią Świdrowską wdzięczny jestem Krystynie Piotrowskiej (Warszawa) oraz Mariuszowi Paszkowskiemu (Kraków).

Z wdzięcznością wspominam także Katarzynę Błachowską (Warszawa), Tomasza Dzieńkowskiego (Lublin), Eike Eckerta (Berlin), Jolantę Kalagę (Warszawa), Jerzego Kuśnierza (Zamość), Aleksandra E. Musina (St. Petersburg), Karin Reichenbach (Lipsk), Guntera Schöbla (Unteruhldingen) oraz Michaela Strobla (Drezno). Osobne podziękowania należą się pracownikom archiwów Państwowego Muzeum Archeologicznego, Polskiej Akademii Nauk oraz Archiwum Akt Nowych (Warszawa).

Czytelnik niniejszego artykułu kilkakrotnie natrafi na jego łamach na nazwiska badaczy rosyjskich czy ukraińskich. Zapisano je w formie spolszczonej, w jakiej najczęściej przywołuje się w Polsce te postaci, jednakże za pierwszym razem, gdy osoby te pojawiają się w tekście głównym podano także zapis imienia i nazwiska w cyrylicy.

2 Zofia Krońska z domu Przedrzymirska była ciotką Zofii Wartołowskiej - siostrą jej mamy, Bronisławy Przedrzymirskiej. Zofia Przedrzymirska wyszła za mąż za Aleksandra Krońskiego, z którym miała dwójkę dzieci: Tadeusza i Ninę. W 1945 r. (po powrocie do Warszawy) Zofia Krońska zamieszkała w domu przy ul. Wspólnej. Dla porządku warto może dodać, iż sam Tadeusz Kroński wrócił do Warszawy dopiero w 1949 r.; por. Franaszek 2011, 428. różnorakie następstwa, w tym całkowita zależność powojennej Polski od ZSRR, determinowały życiowe wybory wielu z nich, wpłynęły także na dzieje badań nad Grodami Czerwieńskimi. Z tego więc względu zdecydowałem się nadać memu szkicowi tytuł nawiązujący do tytułu wspomnianego już tomu korespondencji Cz. Miłosza.

Choć moim zamiarem było ukazanie historii badań nad Grodami Czerwieńskimi po 1945 r., to jednak dla właściwego przedstawienia ówczesnych wydarzeń koniecznym było krótkie cofnięcie się do okresu II Rzeczpospolitej i lat 1939-1945. Historia badań nad rolą archeologii, mediewistyki w relacjach polsko-niemieckich w XX w. jest już od dawna ważną częścią naszej dyscypliny (por. np. Piskorski et al. [red.] 2002; Neighbours... 2004; 2005), studia nad archeologicznymi aspektami relacji polskoukraińskich (zob. np. Lech 2006; Piotrowska 2006; Sytnyk 2006; Kozłowski 2013) czy też badania porównawcze nad archeologią uprawianą w krajach komunistycznych (por. ostatnio Lozny [red.] 2017) są mniej zaawansowane. Mam nadzieję, że poniższe uwagi zostaną uznane za wartościowy przyczynek do badań nad tymi zagadnieniami.

Poczynić należy jeszcze dwa zastrzeżenia: w niniejszym opracowaniu całkowicie pominałem problematykę archeologiczna - wyniki aktualnych prac nad zabytkami z Czermna i Gródka publikowane są w powszechnie dostępnych wydawnictwach (por. Wołoszyn 2013; Florek, Wołoszyn [red.] 2016) i do tych prac odsyłam ewentualnych Czytelników. Zrezygnowałem także z analizy pojęcia Grody Czerwieńskie i prezentacji dyskusji na temat zasadności identyfikacji Czermna ze znanym z latopisu grodem Czerwień. W niniejszym artykule przyjęto, że region Grodów Czerwieńskich to teren w okolicach dzisiejszej miejscowości Czermno, w środkowym dorzeczu Bugu, zasadniczo na jego lewym brzegu. Ważną rolę odgrywać mógł tu także gród w miejscowości Gródek - noszący we wczesnym średniowieczu nazwę Wołyń.

3 W ramach projektu Złote jabłko polskiej archeologii... (por. przyp. 1) przeprowadzana jest ponowna analiza przekazów pisanych dotyczących Grodów Czerwieńskich i środkowego Pobuża - wyniki tych prac zostaną zaprezentowane już w tym roku; por. Wołoszyn (red.) w przygotowaniu; zob. też Janeczek 2016.

W tomie tym zostanie także szeroko zaprezentowana historia badań nad Grodami Czerwieńskimi, przez archeologa (m.in. M. Wołoszyn), ale przede wszystkim historyka historiografii - K. Błachowską. 


\section{OKRES II RZECZYPOSPOLITEJ}

Powstanie narodowych historii jest produktem XIX-wiecznej Europy, wówczas, jak stwierdza ostatnio Stefan Berger: „The need to write history as an identitarian project can be traced all the way from Iceland in the West to Russia in the east and from Norway in the north to the Iberian peninsula, Italy and the Balkans in the south" (Berger 2015, 81). Z oczywistych powodów w tworzeniu owych narodowych wizji przeszłości ogromną rolę odgrywały studia nad początkami danej wspólnoty, przy czym owe - znów z oczywistych powodów - chwalebne, bohaterskie początki cofano w odległa przeszłość, najlepiej w wieki średnie (por. na ten temat m.in. Pomian 2002; Evans, Marchal [red.] 2011; Wood 2013).

W tym kontekście interesujące jest, iż polska archeologia bardzo długo była przede wszystkim pre- czy prahistorią. Próby systematycznych badań nad wiekami średnimi podjęte zostały właściwie dopiero u schyłku okresu międzywojennego. Zdecydowanie prym wiódł tutaj ośrodek poznański, zasługa to Józefa Kostrzewskiego (1885-1969), ale i Romana Jakimowicza (1889-1951), który - habilitowawszy się w Poznaniu w 1934 r. - zobowiązany był prowadzić w stolicy Wielkopolski zajęcia z zakresu swojej specjalizacji, a więc wieków średnich. W latach 1936-1939 rozpoczęto prace wykopaliskowe na terenie grodzisk w Gnieźnie, Kłecku oraz Poznaniu, które miały fundamentalne znaczenie dla wyobrażeń o Polsce Pierwszych Piastów (por. Brzostowicz 2014; Buko 2014; Kozłowski 2014).

Ani na uniwersytecie w Krakowie, ani we Lwowie nie podjęto wówczas podobnych badań.

W Warszawie w 1936 r. Zakład Archeologii Przedhistorycznej Uniwersytetu Warszawskiego został przemianowany na Zakład Archeologii Przedhistorycznej i Wczesnodziejowej (Kozłowski 2014), w tym też roku - pod kierunkiem W. Antoniewicza i Z. Wartołowskiej - podjęto studia nad wspomnianym już grodziskiem w miejscowości Sąsiadka. Z faktu, iż stanowisko to jest istotne dla studiów nad pograniczem polsko-ruskim, zdawano sobie oczywiście sprawę, Z. Wartołowska interesowała się tym obiektem jednak przede wszystkim jako grodziskiem, jego „pograniczność” miała tu raczej drugorzędne znaczenie ${ }^{4}$.

4 Badaczka ta poświęciła swoją, obronioną w 1935 r., pracę magisterską właśnie grodziskom (na obszarze między
Również badania nad archeologią wieków średnich wschodnich ziem II RP pozostawały w stadium początkowym. Przypomnieć tu należy o badaniach wykopaliskowych osady w Gródku na Wołyniu, prowadzonych w latach 1926-1927 przez Michała Drewko (1887-1964; por. Piotrowska 2006, 74; zob. także Musianowicz 1979), z kolei Józefa Jodkowskiego (1890-1950), a następnie Zdzisława Durczewskiego (1908-1944) na terenie Starego Zamku w Grodnie w latach 30-tych XX w. (por. Durczewski 1939). Na terenie Kryłosu nieopodal Halicza badania prowadził ukraiński archeolog Jarosław Pasternak (Яросла́в Іва́нович Пастерна́к; 1892-1969; na ten temat por. Piotrowska 2006, 7680; zob. Pasternak 1938).

W 1933 r. wspomniany już R. Jakimowicz opublikował studium na temat wyprawy kijowskiej Bolesława Chrobrego. Opracowanie to - powstałe bez wattpienia w duchu tzw. eksperymentu wołyńskiego, w ramach którego starano się przekonać ukraińskie elity do akceptacji państwa polskiego, oferującego w zamian dość dużą swobodę w zakresie życia kulturalnego, a i gospodarczego - pozostaje wartościowym studium kultury materialnej wczesnośredniowiecznego Wołynia (Jakimowicz 1933; por. Piotrowska 2006, 80; Wołoszyn 2012, 257-258).

We Lwowie lat 20-tych i 30-tych ubiegłego stulecia wiodącymi archeologami byli Tadeusz Sulimirski (1898-1983) i Leon Kozłowski (18921944), a więc prehistorycy (por. Chochorowski 2016; Kozłowski, Sytnyk [red.] 2010). Miasto to było jednak także bardzo prężnym ośrodkiem historycznym, w tym mediewistycznym (por. Maternicki, Zaszkilniak [red.] 2007; Maternicki et al. [red.] 2014). Warto w tym kontekście podkreślić, iż w latach 30-tych XX w. obserwujemy w tym ośrodku wyraźny wzrost zainteresowania Ziemią Czerwieńską, w tym archeologią tego regionu.

Sanem, Wisłą, Bugiem i Narwią). Za inicjatora badań nad Sąsiadką/Sutiejskiem należy uznać krakowskiego etnologa Kazimierza Moszyńskiego (1887-1959), wypowiadającego się na temat tego stanowiska już od 1919 r. Z jego inicjatywy przeprowadzono analizy językoznawcze samej nazwy grodu, podjęto także pierwsze ,wycieczki terenowe” na teren grodziska; o początkach badań tego założenia zob. Kalaga 2013, 17-18 (tu dalsza lit. przedmiotu). 
Od 1935 r. staraniem m.in. Stanisława Zakrzewskiego (1873-1936) ${ }^{5}$ wydawano we Lwowie czasopismo Ziemia Czerwieńska (por. Sierżęga 2011, 236-243). Pod pojęciem tym rozumiano ogólnie południowo-wschodnie województwa II Rzeczypospolitej, w tym także interesujący nas region nad środkowym Bugiem, np. w wydrukowanej ok. 1939 r. książeczce Lwów i ziemia czerwieńska wzmiankowane są m.in. grody w Czermnie-Czerwieniu oraz Gródku-Wołyniu jako najstarsze części składowe Ziemi Czerwieńskiej'.

Gazeta Lwowska z dnia 2 XII 1936 donosiła o planach powołania do życia we Lwowie Muzeum Pradziejów Ziemi Czerwieńskiej (por. Dwie nowe...). Otwarcie placówki planowano na rok 1940, z oczywistych powodów do niego nie doszło, we wrześniu 1939 r. pracujący na rzecz działu prehistorycznego planowanego muzeum L. Kozłowski został aresztowany i wywieziony do Moskwy (Lech 2006, 46; por. Kozłowski, Sytnyk [red.] 2010), z kolei zbiory lwowskie zostały świadomie przemieszane przez okupantów (Matwijów 1996, 20-23; por. także Zarubij 2009).
Zapewne - gdyby nie wybuch wojny - podjęto by we Lwowie szersze badania nad południowo-wschodnimi województwami II RP, w tym archeologiczne. Stało się jednak inaczej, planowane Muzeum Pradziejów Ziemi Czerwieńskiej nie powstało, a Ewa (1900-1972) i Karol Maleczyńscy (1897-1968) angażujący się w badania tego regionu znani są dziś jako badacze Śląska (por. Matwijowski 2016).

Mimo wyliczonych powyżej inicjatyw, J. Kostrzewski mógł z pełnym przekonaniem stwierdzić, we wstępie do pisanej w trakcie II wojny światowej Kultury prapolskiej, iż "[...] ostatni okres naszych pradziejów [wieki średnie - M.W.] długo traktowany był u nas po macoszemu" (Kostrzewski 1947, 7).

Choć zagadnienie lokalizacji Grodów Czerwieńskich było niejednokrotnie rozpatrywane w dwudziestoleciu międzywojennym, a zespoły grodowe w Czermnie i Gródku były znane już od XIX w. to nie podjęto $\mathrm{w}$ tym czasie na ich terenie żadnych prac badawczych. Paradoksalnie, do pierwszych prac wykopaliskowych w Czermnie doszło w $1940 \mathrm{r}$.

\section{OKRES II WOJNY ŚWIATOWEJ}

W ramach paktu Ribbentrop-Mołotow, podpisanego 23 VIII 1939 r., granica niemieckiej i radzieckiej strefy okupacyjnej miała - w wypadku ziem II RP - przebiegać wzdłuż linii Sanu, Wisły i Pisy: teren Grodów Czerwieńskich winien więc znaleźć się na obszarze kontrolowanym przez Moskwę. Zawarta między Berlinem a Moskwą umowa z dnia 28 IX 1939 r. stanowiła jednak, iż obszary pomiędzy Wisłą a Bugiem zostaną oddane pod kontrolę III Rzeszy. Tym samym stanowiska w Czermnie i Gródku znalazły się na wschodnim pograniczu Generalnej Guberni (na temat wspomnianych wydarzeń zob. artykuły w Rotfeld, Torkunow [red.] 2010; położenie Czermna i Gródka względem wy-

5 St. Zakrzewski przez cały okres międzywojenny interesował się zagadnieniem pogranicza polsko-ruskiego, w tym problematyką Grodów Czerwieńskich; por. na ten temat Błachowska 2005; Tyszkiewicz 2008; Wołoszyn 2012, 256-257.

6 Maleczyński et al. 1939, 16. Warto w tym miejscu dodać, iż dziś zasadność łączenia terminu Grody Czerwieńskie i Ruś Czerwona poddawana jest w wątpliwość; por. Janeczek 2013. mienionych tu linii granicznych zob. Wołoszyn 2012, ryc. 19).

17 IX 1939 oddziały Armii Czerwonej wtargnęły na teren II Rzeczypospolitej, przy czym działaniom militarnym towarzyszyła niezwykle intensywna akcja propagandowa, w której okupacja niemal połowy kraju przedstawiona została jako akt wyzwolenia białoruskich i ukraińskich mas pracujących spod wielowiekowego polskiego jarzma (por. np. Stryjek 2002; Hryciuk 2009).

W tym kontekście w ówczesnej publicystyce radzieckiej pojawiają się m.in. Grody Czerwieńskie. Należy tu wskazać na tekst Borysa Grekowa (Борис Дмитриевич Греков; 1892-1953), jednego z najważniejszych mediewistów ZSRR, który po wojnie miał współpracować z polskimi badaczami w badaniach nad Czermnem i Gródkiem (por. niżej). 26 X 1939 r. wygłosił on w Moskwie, na posiedzeniu Akademii Nauk, referat na temat historii zachodniej Ukrainy, tekst wystąpienia ukazał się drukiem w listopadowym numerze pisma Nowyj Mir (Новый Мир; Grekow 1939). We wstępie akademik Grekow wyraził radość z powodu sukcesów Armii Czerwonej we wrześniu 1939 r., a następnie 
przedstawił smutne dzieje zachodniej Ukrainy. Grody Czerwieńskie traktowane są tutaj jako synonim pojęcia Ruś Halicko-Wołyńska, a niekiedy wręcz zachodniej Ukrainy. Jak łatwo się domyślić, wyjątkowo przygnębiająca historia tego regionu wiąże się z obecnością tam Polski i Polaków.

Wprawdzie archeolodzy ZSRR interesowali się naukowym „zagospodarowaniem” zdobyczy terytorialnych Stalina, w ówczesnym Leningradzie odbyło się nawet - w listopadzie 1939 r. specjalne posiedzenie poświęcone temu zagadnieniu (por. Zapiska, 1940), jednakże do realizacji jakichkolwiek badań wykopaliskowych w latach 1939-1941, które np. w sposób ,prawidłowy” wyjaśniałyby formowanie się pogranicza polsko-ruskiego nie doszło.

Latem 1940 r., pomiędzy 15 lipca a 15 sierpnia miały miejsce natomiast pierwsze prace wykopaliskowe w Czermnie, kierował nimi Lewko Czykałenko (Левко Євгенович Чикаленко; 18881965), ukraiński archeolog, czynny zawodowo na terenie II RP, który pod koniec II wojny światowej opuścił Ukrainę wraz z oddziałami niemieckimi, a w 1948 r. wyemigrował do USA. Tym samym na „wyzwolonej” przez Armię Czerwoną Ukrainie był on persona non grata (por. Petehyrycz, Fyłypczuk 1998; Kozłowski 2013, 238).

W rezultacie, do niedawna o pracach w Czermnie w 1940 r. nie wiedziano zbyt wiele. Kilka rysunków wyrobów kościanych z Czermna, z badań 1940 r. zostało zaprezentowanych w pracy na temat wyrobów kościanych z Wołynia (Ratycz 1959, ryc. II:23a, III:12, IV:27-28) ${ }^{7}$. Informacje o pracach w Czermnie w 1940 r. pojawiły się także w przygotowanym w Kanadzie opracowaniu J. Pasternaka, poświęconym archeologii Ukrainy (Pasternak 1961, 653). Bazują one na danych przekazanych przez Czykałenko w liście z 1-go IX 1960 r.

Obszerne sprawozdanie $\mathrm{z}$ prac w Czermnie w 1940 r., pisane w Chełmie, zapewne zaraz po zakończeniu badań, zostało odkryte we Lwowie w 1990 r. w archiwum Instytutu Nauk Społecznych Narodowej Akademii Nauk Ukrainy i opublikowane w 1998 r. (por. Czykałenko 1998; zob. też Petehyrycz, Fyłypczuk 1998).

Poza sprawozdaniem, jakie opublikowano we Lwowie w 1998 r., L. Czykałenko sporządził także

7 Nazwisko L. Czykałenko nie pojawia się w tej publikacji ze wspomnianych już względów politycznych.
- znacznie krótszy - opis swych prac, który przesłał jeszcze latem 1940 r. polskiej archeolog Z. Wartołowskiej. Danuta Piotrowska opublikowała plan stanowiska w Czermnie, jaki był dołączony do listu Czykałenko (Piotrowska 2006, ryc. 27), sam list został ostatnio udostępniony przez piszącego te słowa (Wołoszyn 2016b, 207-208, ryc. 5).

W swoim sprawozdaniu L. Czykałenko stwierdza, iż prace wykopaliskowe realizował na zlecenie Ukraińskiego Komitetu Centralnego (Український центральний комітет), a także (ukraińskich) gmin w Hrubieszowie i Bełzie (Czykałenko 1998, 1). W. Antoniewicz w trakcie konferencji w Hrubieszowie w 1953 r. mówił, iż badania te realizowane były „,z ramienia Niemców” (przy czym wykopaliska datuje na 1942 r.; por. niżej). Wydaje się, że wypowiedź warszawskiego archeologa należy traktować jako skrót myślowy - Ukraiński Komitet Centralny, wspominany przez Czykałenko, był instytucją w pełni zależną od niemieckich władz okupacyjnych.

Organizacja ta została powołana do życia wiosną 1940 r. Na jej czele stał Włodzimierz Kubijowycz (Володимир Кубійович; 1900-1985), z wykształcenia geograf, do 1939 r. docent Uniwersytetu Jagiellońskiego, usunięty z uczelni za swe (proukraińskie i antypolskie) zaangażowanie polityczne. Celem Kubijowicza było przekonanie niemieckich władz, w tym samego Hansa Franka (1900-1946), do realizacji we wschodniej części Generalnej Guberni polityki proukraińskiej (i antypolskiej). Komitet miał być zaś instytucją wspierającą rozwój ukraińskiego ruchu narodowego we wschodniej części GG (por. Sowa 1998; Grelka 2005, 192-208; Golczewski 2010, 947-950; 2017; Markiewicz 2016).

Wydaje się pewne, iż badania w Czermnie realizowane były $w$ ramach działań zmierzających do rozbudzenia „ukraińskiego ducha narodowego", trudniej udowodnić, by cieszyły się one zainteresowaniem władz niemieckich. H. Frank przebywał we wschodniej części GG pomiędzy 24 i 29 VII 1940, a więc w czasie, gdy w Czermnie trwały badania wykopaliskowe (odwiedził wówczas: Chełm, Lublin, Biłgoraj, Nałęczów, Kazimierz nad Wisłą, Zamość, Bełżec). Niestety o Czermnie brak wzmianek w dzienniku Franka (Diensttagebuch..., 254-259), brak ich także w książce Kubijowicza poświęconej historii Ukraińskiego Centralnego Komitetu (Kubijowicz 1975), jak i na łamach Krakiwśkich Wisti (Краківські вісті; pismo wydawane przez Komi- 
tet $)^{8}$. Bez wątpienia dla wyjaśnienia okoliczności, w jakich doszło do badań w Czermnie w 1940 r., konieczne są dalsze poszukiwania archiwalne ${ }^{9}$.

Oczywistym jest natomiast, iż badania te wzbudziły zaniepokojenie strony polskiej. Jednoznacznie świadczy o tym list Z. Wartołowskiej do W. Antoniewicza z 1-go VII 1940 r., w którym pisze ona:

Wiele Szanowny Panie Profesorze, najmocniej przepraszam, że tak poszukuje Pana Profesora, ale po przyjeździe ze wsi w piatek dowiedzatam sie że dr. Czekalenko otrzymat pieniadze od Ukraińców na wykopaliska $i$ za rada prof. Korduby wybrat grodzisko w Czermnie. Prof. Korduba chce tam znaleść Czerwień dawny $i$ wszystko wskazuje na to że tak jest istotnie. P. Czekalenko byt u mnie w domu kilka razy żeby się nauczyć ode mnie jak się kopienie mógt mnie zastać bo miesiac byłam na wsi. $W$ chwili obecnej jest juz na robotach. Panie Profesorze może możnaby jeszcze co zrobić żeby albo niemcy cofnęli pozwolenie na kopanie z powodu braku kwalifikacji p. Czekalenki, albo może udałoby się wyttumaczyć prof. Kordubie że takie kopanie jest zniszczeniem to możeby na inne grodzisko przerzucit p. Czekalenko.

Do prof. Korduby w ogóle mam żal.

Panie Profesorze raz jeszcze przepraszam za naprzykszanie się $i$ za ten list pisany $w$ sklepiku na rynku i bardzo proszę o jakaś wiadomość co Pan Profesor myśli o tem [sic] wszystkim [...] (por. Wartołowska, list 1940).

Pojednawczy w tonie jest - wspomniany już - list Czykałenko do Wartołowskiej z 16-go VIII 1940. Autor badań w Czermnie pisze m.in.:

Wielce Szanowna Pani Zofio!

To będzie mój pierwszy list $w$ języku polskim! Otóż proszę o wybaczenie. Możliwe tylko zaciekawienie treścia zmusi Pani jego przeczytać do końca. Przystępuję!

Zaproszono mnie jako jedynego przedhistoryka ukrainca, który przebywa na ziemiach Gener.

8 Wisti szeroko informowały o wizycie Franka m.in. w Chełmie, brak wzmianki o badaniach w Czermnie wydaje się więc być dość symptomatyczny.

9 Takie działania podejmuje obecnie Andrzej Kokowski (Lublin). Wstępne wyniki swych badań przedstawił on w trakcie konferencji z cyklu Grody Czerwieńskie - złote jabłko polskiej archeologii (seminarium nr 4, Kraków, 7-9 XII 2016), wygłaszając referat pt. Czermno pod lufami - czyli wykopaliska w trakcie II wojny światowej.
Gouvern. Zpoczatku chciatem odmówić się, ale pomyślatem troche a też prositem o rade prof. Kordubę i datem zgodę. Lepiej niech będzie przy kopaniu ktoś, kto chociaż coś rozumie jak sie prowadza wykopaliska. Warunkiem swego uczestnictwa postawitem 1). obecność dobrego geometry, 2). obecn. dobrego fotografa i 3). możliwość w każdej chwili obecności architekta.

Naturalnie że $w$ obecnych warunkach wojny przecież żaden z tych warunków nie byt dotrzymany. Nie wyjechatem z powrotem a zostatem się $i$ zostane się do końca pracy, ale za to ze swej strony wszystko zrobiłem, żeby nie zepsuć nic. Dlatego Grodu Czerwnia nawet łopata nie dotknałem, a kopałem naokoło.

$[\ldots]$

Ciekawy jestem czy będzie Pani od czytania tego listu chociaż o połowe tak zmęczona jak ja przy jego pisaniu.

Serdecznie oddany Pani $[\ldots]$

(por. Czykałenko list 1940; Wołoszyn 2016b, ryc. 5).

Badania w Czermnie w 1940 r. to oczywiście nie jedyne wykopaliska, jakie miały miejsce w Polsce w trakcie niemieckiej okupacji (por. Kozłowski 2012), już jednak ze względu na ich znaczenie dla relacji polsko-ukraińskich pełna rekonstrukcja ówczesnych wydarzeń jest pilnym postulatem badawczym. Z punktu widzenia niniejszego artykułu istotna jest ewentualna rola w ówczesnych wydarzeniach W. Antoniewicza ${ }^{10}$.

10 Warto tu może jedynie wspomnieć o Prof. Kordubie, do którego żal wyraża Wartołowska. Myron Korduba (Мирон Михайлович Кордуба; 1876-1947), пајwybitniejszy uczeń Michała Hruszewskiego (Михайло Грушевський; 1866-1934), twórcy nowoczesnej ukraińskiej historiografii (por. Adamski 2011), zasadniczo zajmował się okresem nowożytnym (m.in. powstaniem Chmielnickiego), ale i średniowieczem, w tym formowaniem sie granicy polsko-ruskiej. W 1929 r. Korduba przeniósł się ze Lwowa do Warszawy, gdzie objął stanowisko profesora historii Ukrainy na UW, z czasem włączył się także do prac Ukraińskiego Naukowego Instytutu w Warszawie (UNI; na temat tej instytucji zob. Kozak 2008). W 1940 r. Korduba przeniósł się z Warszawy do Chełma, gdzie przebywał aż do grudnia 1941. W Chełmie Korduba, pracując jako nauczyciel historii $\mathrm{w}$ miejscowym gimnazjum, intensywnie uczestniczył w życiu ukraińskim, opublikował kilka książek, a także szereg artykułów na łamach Krakiwśkich Wi- 
W cytowanym już liście Zofia Wartołowska pyta: ,[...] może możnaby jeszcze co zrobić żeby albo [?] niemcy cofnęli pozwolenie na kopanie z powodu braku kwalifikacji p. Czekalenki [...], albo może udałoby się wytłumaczyć prof. Kordubie że takie kopanie jest zniszczeniem to możeby na inne grodzisko przerzucił p. Czekalenko“ (por. wyżej).

Jak wiadomo, W. Antoniewicz tuż po wojnie oskarżany był o współpracę z niemieckimi władzami okupacyjnymi, a konkretnie o pracę na rzecz Institut für Deutsche Ostarbeit. Posadę w IDO zawdzięczał Antoniewicz protekcji Hansa Reinertha (1900-1990), a w swojej działalności podlegał Wernerowi Radigowi (1903-1985). Dziś, po ukazaniu się serii publikacji Stefana Karola Kozłowskiego (2009a; 2009b; 2010; 2012; 2013), a także dyskusji między tymże a Jackiem Lechem (por. np. Lech 2009; 2010), wiemy dość dużo na temat ówczesnych wydarzeń.

Z dotychczas publikowanych dokumentów wynika, iż Antoniewicz pracował dla IDO w latach 1941-1942. S.K. Kozłowski publikuje - pisany po polsku - powojenny (z 29 XI 1946) list Reinertha do Antoniewicza, w którym ten pierwszy wspomina, iż:

Natychmiast po otrzymaniu wiadomości o Pańskim smutnym położeniu $w$ r. 1940, udało mi się zaangażować Pana jako wspótpracownika. Gdy jednak instytut przyznat Panu bardzo niezadowalajace miejsce pracy, chciatem osiagnać jak Panu w r. 1942 donositem, ażeby Panu przyznano zadanie badań naukowych $w$ dziedzinie gotyku [?]

(por. Kozłowski 2009a, 171).

Uprzejmości i wiedzy Guntera Schöbla z Pfahlbaumuseum Unteruhldingen, Karin Reichenbach (Lipsk), a także Michaela Strobla (Drezno) zawdzięczam dotarcie do oryginału listu Reinertha z $1946 \mathrm{r}$. Okazuje się, że list pisany był jednak po niemiec$\mathrm{ku}^{11}$, a na język polski przełożył go niejaki Bernhard

sti, poświęconych tematyce historycznej (por. Świstowski 2009; Fedoriszczak 2013).

Relacje polsko-ukraińskie były w Chełmie napięte - ogniskowały się one wokół sporu o katedrę, przy czym władze niemieckie wyraźnie faworyzowały stronę ukraińską (por. Golczewski 2017, 294-304). Wydaje się oczywiste, że Z. Wartołowska, sama pracownik UW, miała żal do Korduby za zaangażowanie się w sprawy ukraińskie we wschodniej części GG.

11 S. K. Kozłowski uważa, iż wersja polskojęzyczna jest oryginałem; por. Kozłowski 2009a, 171.
Woźny ${ }^{12}$. W stosunku do powszechnie znanego polskiego tekstu oryginał niemiecki pozwala stwierdzić, iż Reinerth zorganizował Antoniewiczowi prace w IDO już w 1940 r., natomiast badania naukowe nad gotykiem, o których mowa $\mathrm{w}$ polskim thumaczeniu, to w rzeczywistości „Gotenforschung” (jak zresztą trafnie przypuszczał S. K. Kozłowski [2012, 190]). Reinerth pisze m.in. ${ }^{13}$

Ich habe aber gleich, als ich von Ihrer traurigen Lage erfuhr, 1940 dem Ostinstitut in Krakau vorgeschlagen, Sie als wissenschaftl[ichen]. Mitarbeiter einzusetzen. [...?] hatte, wie ich Ihnen [...?] Das ist auch gelungen. Nachdem aber das Institut Ihnen nur eine sehr unbefriedigende Stellung übertragen hatte, wollte ich erreichen, wie ich damals 1942 schrieb, ten daßnsch danen [...?] unabhängiger, größerer wissenschaftlicher Auftrag im Rahmen der Gotenforschung zu vermittetn übertragen würde

(por. Reinerth, szkic listu 1946).

Trudno jednoznacznie rozstrzygnąc, czy i w jakim charakterze Antoniewicz zatrudniony był w 1940 r. w IDO. Prośba Z. Wartołowskiej, formułowana w liście z 16-go VIII 1940 r., aby wpłynął on na władze niemieckie, tak aby cofnięto pozwolenie na badania w Czermnie, wiąże się - moim zdaniem - nie z osobistymi kontaktami Antoniewicza z jego niemieckimi kolegami-archeologami, a właśnie z jakimiś związkami z IDO.

Z całą pewnością, gdy 7-go VIII $1941 \mathrm{r}$. Z. Wartołowska, planując rekonesans w okolicach Sąsiad$\mathrm{ki}^{14}$, prosiła W. Antoniewicza

12 Cytuję początkowe (a) i końcowe (b) fragmenty listu (zrekonstruowane przez K. Reichenbach; przekreślenia w oryginale; pytajniki - K. Reichenbach):

a - „Prof. Dr. Hans Reinerth, der Ihnen bekannt ist und mit mir gleichzeitig im Überlinger Krankenhaus liegt, hat mich gebeten, Ihnen die folgende Mitteilun Bitte zu übermitteln:";

b - „Ich hoffe von Herzen, dass es Ihnen und Ihrer Familie gut geht. Bitte schreiben Sie mir recht bald. Am besten über den Poln. Comman-Danten im Kreise Überlingen, Herrn Bernhard Wozny, der die Liebenswürdigkeit hat, diesen Brief zu übersetzen u. zu vermitteln"; por. Reinerth, szkic listu 1946.

13 Tekst zrekonstruowany przez K. Reichenbach, miejsca nieczytelne oznaczono pytajnikiem, przekreślenia $\mathrm{w}$ oryginale.

14 Trudno do końca zrozumieć powody, dla których Z. Wartołowska zdecydowała się na tego typu wycieczke terenową w dwa miesiące po rozpoczęciu Fall Barbarossa. 
[...] o jakieś zaświadczenie, którym mogłabym się wylegitymować w moich wędrówkach, i które pozwoliłoby mi zabrać ewentualnie mape, kompas czy aparat fotograficzny chodziło Wartołowskiej o możliwości Antoniewicza związane z jego pracą dla IDO. Prośbę swą bowiem kieruje do Antoniewicza

[...] w zwiazku z nowo objętym przez Pana Profesora stanowiskiem [...]

(por. Wartołowska, list 1941).

Wspomniany już list Czykałenko do Wartołowskiej opatrzony był adnotacją „,Bez prawa ogłaszania w druku" (brak daty i autora tej notatki; por. Wołoszyn 2016b, ryc. 5). Zakaz ten dyrekcja PMA traktowała poważnie, np. w liście do Stefana Noska (1909-1966) z dnia 3 XII 1947 r. M. Drewko, ówczesny wicedyrektor tej placówki, pisał m.in.:

Równocześnie P.M.A. przesyta Panu w odpisie kilka notatek odnoszacych się do Czermna w pow. tomaszowskim. List ob. Lewki Czikalenko do ob. Zofii Wartołowskiej z dn. 16 sierpnia 1940 r. na wyraźne zastrzeżenie właścicielki nie może być ogłoszony drukiem ani w całości ani $w$ wyjatkach

(por. Drewko, list 1947).

Nie jest dla mnie jasne, dlaczego list Czykałenko został objęty zakazem publikacji, w jego treści nie ma nic bulwersującego. Zastanawia fakt, iż W. Antoniewicz, wspominając o badaniach Czykałenko w trakcie konferencji w Hrubieszowie w 1953 r. (por. niżej), datował te prace na rok 1942. Jest więcej niż prawdopodobne, iż znał on treść listu Czykałenko, wynika to nie tylko z naszej wiedzy o bliskich relacjach z Z. Wartołowską (por. Kozłowski 2009a, 130), ale i analizy jego wystapienia z 1953 r. Znajdujemy tu bowiem informację, iż „[...] zabytki uzyskane $\mathrm{w}$ czasie tych poszukiwań były zdeponowane w Muzeum w Chełmie [...]" (por. niżej). Informacja na ten temat znajduje się w liście Czykałenko:

Zebratem wszystkie skorupy $i$ wszystkie nadajace się do oznaczenia kości, razem $140 \mathrm{~kg}$.
Wszystko to dowioztem do Chetma, gdzie będzie ulokowane $w$ byłem gimnazjum polskiem a teraz ukraińskiem

(por. Czykałenko list 1940; por. Wołoszyn 2016b, 208, ryc. 5).

Jest charakterystyczne, że - zazwyczaj tak solidny - Konrad Jażdżewski (1908-1985) pisał w swym opracowaniu na temat wojennych badań w Czermnie, iż Czykałenko prowadził swoje prace w 1941 r., po czym dodaje:

Co się stało z wynikami tych badań, nie wiadomo blizej; zabytki stamtad znajduja się może w zbiorach archeologicznych we Lwowie. Pewne informacje o swych poszukiwaniach przestat L. Czikalenko - o ile mi wiadomo - prof. $d r$ W. Antoniewiczowi $w$ Warszawie

(por. Jażdżewski 1959, 69-70).

W świetle mego obecnego rozeznania wydaje się, iż jedynym powodem, dla którego W. Antoniewicz przedatował prace wykopaliskowe w Czermnie z 1940 na rok 1942, a z kolei sprawozdanie Czykałenko przechowywane w PMA objęte zostało zakazem publikacji, była obawa Antoniewicza, by nie upowszechniać informacji o zdarzeniach, które mogły posłużyć jako dowód na jego związki z IDO, czy szerzej niemiecką władzą okupacyjną już w $1940 \mathrm{r}$.

Kończąc uwagi na temat wojennych badań nad Grodami Czerwieńskimi, wspomnieć wypada o niemieckim mediewiście, urodzonym w Poznaniu Gottholdzie Rhode (1916-1990). W - skądinąd znakomitej - monografii na temat wschodniej granicy Polski wspomina on swoje wędrówki wzdłuż brzegu Bugu w 1941 r. (Rhode 1955, 62, przyp. 142). Niestety Rhode pojawił się nad Bugiem nie w służbie Klio, a jako żołnierz Wehrmachtu, przygotowując się do ataku na ZSRR (od 4 V 1941 był Rhode tłumaczem w sztabie 8. Dywizji piechoty, poczta polowa nr 21507; jego jednostka wzięła udział w ataku na ZSRR [z rejonu Suwalk] z 22 VI 1942; por. Ecker 2012, 143).

\section{OKRES POWOJENNY}

Jak wiadomo, odbudowa zniszczonego wojną kraju, w tym placówek naukowych, rozpoczęła się niemal natychmiast po ustaniu niemieckiej okupacji. W 1945 r. wznowiono także prace wykopaliskowe na wielu stanowiskach archeologicznych, w tym na grodzisku w Sasiadce (trwały one od 28-go VIII do 31-go IX 1945; por. Wartołowska, sprawozdanie 1945; na temat powojennej odbudowy z perspektywy archeologii zob. Abramowicz 1991, 139-146). 
Okres powojenny przynosi szereg zmian w polskiej archeologii, tak organizacyjnych, jak i merytorycznych. W tym pierwszym wypadku chodzi przede wszystkim o powstanie dużych, pozauniwersyteckich placówek badawczych, zatrudniających wielu archeologów, w drugim o radykalny wzrost znaczenia badań nad początkami Państwa Polskiego. Oba te czynniki zadecydowały o tym, że polska archeologia wieków średnich z dziedziny traktowanej do tej pory „po macoszemu” stała się bardzo ważną jeśli nie najważniejszą częścią naszej dyscypliny.

Brak tu miejsca, by omawiać etapy rozwoju polskiej powojennej archeologii. W $1946 \mathrm{r}$. Witold Hensel (1917-2008) opublikował swój artykuł na temat konieczności uczczenia milenium Państwa Polskiego (Hensel 1946). Hasło to trafiło na podatny grunt, także ze względów politycznych: w kwietniu 1949 powstaje Kierownictwo Badań nad Początkami Państwa Polskiego, w 1953 instytucja ta staje się podwaliną dla działającego od pierwszego stycznia 1954 r. Instytutu Historii Kultury Materialnej PAN (na temat badań milenijnych Abramowicz 1991, 146-162; 2005; Lech 1997-1998; 2009; Kurnatowska 2000; Noszczak 2002; Tabaczyńscy 2005; Reichenbach 2016).

Władze nie szczędziły środków finansowych, a ponieważ do najważniejszych osób decydujących o przebiegu badań milenijnych należał Aleksander Gieysztor (1916-1999), historyk, a zarazem ,przyjaciel archeologii i archeologów" (Kowalczyk 2000a; por. także Dąbrowska 2016), bardzo szybko rozpoczęto zakrojone na szeroką skalę badania archeologiczne. Choć formalnie objęły one całą Polskę (por. Buko 2011, ryc. 82), to jednak punkt ciężkości leżał na zachodzie, w Wielkopolsce, na Śląsku i na Pomorzu. Jak na tym tle przedstawiała się kwestia ówczesnych badań nad pograniczem polsko-ruskim?

Jak informuje nas A. Gieysztor: „Inicjatywa podjęcia badań nad problematyką historyczną Grodów Czerwieńskich, nieobca już w chwili rozpoczynania planowych prac nad początkami Państwa Polskiego wyłoniła się na I konferencji metodologicznej historyków polskich w Otwocku w końcu grudnia $1951 \mathrm{r}$. w porozumieniu z delegacją radziecką, na czele której stał akademik B. D. Griekow" (Gieysztor 1953, 303) $)^{15}$.

15 E. Kowalczyk (2000a, 70) podkreśla szczególne, osobiste zainteresowanie A. Gieysztora tym tematem.
W ramach prowadzonych kwerend archiwalnych udało się potwierdzić fakt, iż idea badań w Czermnie i Gródku pojawiła się już w okresie bezpośrednio powojennym. Świadczy o tym korespondencja przechowywana w archiwum Państwowego Muzeum Archeologicznego. I tak w liście z dnia 24-go VII 1946 Zofia Podkowińska (18941975; wówczas wicedyrektor PMA) zwracała się do Urzędu Ziemskiego w Tomaszowie Lubelskim w sprawie grodziska w Czermnie, pisząc m.in.:

Państwowe Muzeum Archeologiczne w Warszawie pragnac ten wyjatkowej wartości i wielkiej wagi z powodu swego znaczenia w historii - zabytek zachować jako pamiatke historyczna i obiekt przyszłych badań naukowych, - zwraca się do Urzędu Ziemskiego z zapytaniem, - jakie wobec dobiegajacej do końca akcji przesiedleńczej ludności ukraińskiej istnieja możliwości podjęcia akcji zabezpieczajacej, celem wytaczenia terenów zabytkowych $w$ Czermnie z pod parcelacji i uzytkowania rolnego i stworzenia rezerwatu naukowego, do którego nie mogtyby być zastosowane postanowienia Ustawy o reformie rolnej i przebudowie ustroju rolnego (por. Podkowińska, pismo 1946).

Z kolei Zdzisław Rajewski (1907-1974), w piśmie z 24-go VIII 1949 (wówczas dyrektor PMA) prosił o zgodę ze strony Ministerstwa Bezpieczeństwa Publicznego na prace $\mathrm{w}$ pasie granicznym archeologa i mierniczego Urzędu Powiatowego w Hrubieszowie. Dalej wyjaśnia on, iż

$W$ zaraniu dziejów istniat na terenie dzisiejszej wsi Gródek potężny gród Wotyń [...]. Państwowe Muzeum Archeologiczne pragnie podjać w przyszłości na terenie tej starożytnej osady badania naukowe, któreby wyjaśnity nierozwiqzane dotad zagadnienie pierwotnego pogranicza polsko-ruskiego, tak ważne dla dziejów obu narodów. Dązac do trwatego zabezpieczenia tego cennego zabytku, niszczonego przede wszystkim przez niwelujaca teren orke, Państwowe Muzeum Archeologiczne podejmuje akcję celem wytaczenia obszaru zabytkowego z pod uzywania gospodarczego i utworzenia zeń państwowego rezerwatu archeologicznego. Realizacji tego zamierzenia sprzyja okoliczność, że miejscowa ludność ukraińska została ostatnio przesiedlona, zaś nowe osiedle powstać ma w pewnym oddaleniu w kierunku na zachód od dotychczasowej wsi (por. Rajewski, zezwolenie 1949). 
Bez wątpienia aktywność PMA w zakresie zarówno opieki konserwatorskiej nad obiektami w Czermnie i Gródku, jak i planach organizacji przyszłych badań naukowych dotyczących Grodów Czerwieńskich wynikała z pozycji warszawskiego muzeum w okresie międzywojennym, jak i z ambicji Ludwika Sawickiego (1893-1972), dyrektora tej placówki w latach 1945-1949. Sawicki, jako jeden z nielicznych wśród polskich archeologów przedwojenny komunista, liczył na to, że jego „słuszny” wybór polityczny sprzed II wojny światowej przyniesie mu apanaże w nowej, powojennej rzeczywistości. Jednakże w 1949 r. Sawicki „,[... znalazł się na bocznym torze" (Abramowicz 1991, 147; por. Piotrowska 2007, 44-45), nowym dyrektorem został (1-go VII 1949 r.) Z. Rajewski, koordynację badań archeologicznych w skali całego kraju w coraz większym stopniu zaczęło przejmować Kierownictwo Badań nad Początkami Państwa Polskiego ${ }^{16}$. Już wkrótce Rajewski - z ramienia Kierownictwo Badań - rozpocznie prace wykopaliskowe w Gródku.

Wspomniana przez A. Gieysztora konferencja metodologiczna w Otwocku trwała od 28-go XII 1951 do 12-go I 1952 i służyć miała marksistowskiej przebudowie polskiej nauki historycznej (por. Stobiecki 1997).

Niestety, ani w tomach pokonferencyjnych (por. Otwock...1953), ani w archiwum PAN w Warszawie, wśród teczek dotyczących konferencji w Otwocku, nie natrafiłem na zapisy na temat planowanych polsko-radzieckich badań na terenie Grodów Czerwieńskich. W tym kontekście kluczowego znaczenia nabierają dokumenty przechowywane w Muzeum Zamojskim w Zamościu, odkryte przez Jerzego Kuśnierza. W jednym z nich, w notatce służbowej sporządzonej przez A. Gieysztora dnia 10-go I 1952, a więc jeszcze w trakcie trwania konferencji, pisze on:

w sprawie wspólnych badań archeologicznych polsko-radzieckich na obszarze Grodów Czerwieńskich.

1. Na odbywajacej siękonferencjimetodologicznej historyków w Otwocku $w$ dn. 28.XII.52 r., podniesiono myśl wspólnych badań archeologicznych na obszarze Grodów Czerwieńskich

16 Jak podkreśla J. Lech, odsunięcie Sawickiego i przejęcie PMA przez Rajewskiego wynikało nie tyle / nie tylko z sytuacji politycznej, co z talentu organizacyjnego tego ostatniego; por. Lech 2009, 202; por. też Piotrowska 2007, 49 . i w szczególności wymieniano grodziska w Wotyniu n/Bugiem, Czermnie i okolice Przemyśla. Delegacja radziecka $w$ osobach akad. B. D. Grekowa, akad. E. A. Kosminskiego i prof. P. N. Tretiakowa wyrazita swa zgode $i$ akces $w$ imieniu Akademii Nauk ZSRR, a prof. A. S. Sidorow - w imieniu Państwowego Uniwersytetu im. Łomonosowa w Moskwie.

2. Do załatwienia sprawy po stronie radzieckiej będzie będzie upoważniony Instytut Historii Kultury Materialnej Akademii Nauk ZSRR, a zwłaszcza prof. Tretiakow i prof. Rybakow. Po stronie polskiej - Minister Szkół Wyższych i Nauki zwrócit się $w$ tej sprawie po porozumieniu z Ministrem Kultury i Sztuki do Kierownictwa badań nad poczatkami Państwa Polskiego.

3. Kierownictwo Badań nad poczatkami Państwa Polskiego zamierza:

a/ zwołać narade specjalistów /m. in. prof. $d r$ Wt. Antoniewicz i dr Z. Wartołowska, prof. $d r$ Wt. Hotubowicz, prof. dr K. Jażżewski, prof. $d r$ H. Łowmiański, prof. dr S. Nosek/w miesiacu lutym lub marcu br., dla przedyskutowania problematyki i wyboru obiektów badania,

b/ opracować wniosek o powotanie Kierownictwa prac badawczych na obszarze Grodów Czerwieńskich z prof. dr Kazimierzem Majewskim /jako przewodniczacym/

c/ opracować szczególowy program prac badawczych $w$ rb. i ramowy dla całości problemu wraz z preliminarzem wydatków,

d/ wystapić dla Instytutu Historii Kultury Materialnej /w organizacji/ o odpowiedni kredyt dodatkowy w rb.,

el rozpoczać prace terenowe $w$ m-cu lipcu i prowadzić je do połowy października,

f/ doprowadzić do konfrontacji naukowej polsko-radzieckiej w myśl wniosku Kierownictwa badań z 28 maja 1951 r. lodpis w zataczeniul późnq jesienia br.

(por. Gieysztor notatka 1952).

W rezultacie już w 1952 r. formułuje się Kierownictwo Prac Badawczych na obszarze Grodów Czerwieńskich i rozpoczynają - pod kierunkiem Z. Rajewskiego - prace wykopaliskowe w Gródku (16-go VIII 1952 r.) oraz - pod kierunkiem K. Jażdżewskiego - w Czermnie (19-go VIII 1952). O ile w Gródku badania wykopaliskowe trwały przez cztery kolejne sezony aż do $1955 \mathrm{r}$. (badania terenowe zakończono 30-go IX 1955), o tyle w Czermnie zorganizowano tylko jeden se- 
zon wykopaliskowy (prace terenowe zakończono 19-go IX 1952).

W ramach prac nad Grodami Czerwieńskimi realizowano także badania wykopaliskowe na terenie słowiańskiego cmentarzyska kurhanowego w Lipsku-Polesiu, powiat Zamość (badaniami kierował M. Drewko; por. Drewko 1953) oraz na wielokrotnie już wspominanym grodzisku w Sąsiadce (por. obecnie Kalaga [red.] 2013). Badaniami planowano objąć także Przemyśl (Gieysztor 1953, 304), do czego jednak nie doszło. W tym miejscu wspomnieć należy o udziale $\mathrm{w}$ pracach na terenie Grodów Czerwieńskich historyków, t.j. badaczki średniowiecznych szlaków handlowych Teresy Dunin-Wąsowicz (1926-2004; por. Dunin-Wąsowicz 2011), a przede wszystkim Andrzeja Poppe, którego powstałe wówczas studium na temat GródkaWołynia wciąż pozostaje aktualnym kompendium wiedzy na temat tego obiektu (Poppe 1958).

Do uczestników ówczesnych badań należał także Andrzej Abramowicz (1926-2011), archeolog, ale i historyk polskiej archeologii, któremu zawdzięczamy szereg informacji o badaniach Grodów Czerwieńskich w latach 1952-1953 (por. Abramowicz 2010, 15-20, 31-37).

We wrześniu 1953 r. zorganizowano w Hrubieszowie konferencję, na której zaprezentowano wyniki prac z lat 1952 i 1953. Fakt, iż w konferencji uczestniczył moskiewski archeolog Artemij W. Arcichowski (Арте́мий Владимирович Аpцихо́вский; 1902-1978) dodatkowo podniosło jej prestiż. Z Warszawy do Zamościa Arcichowskiego przywiózł Kazimierz Michałowski (1901-1981). Jak wspomina Abramowicz:

Po potudniu toczyly się obrady. Po uroczystym powitaniu gościa $w$ imieniu PAN Gieysztor przewodnictwo oddat Rajewskiemu [...] Dyskusja została przerwana przez delegacje Wojska Polskiego, która słowami 'Witamy największych uczonych świata, uczonych radzieckich' powitała Arcichowskiego i wręczyła mu bukiet kwiatów

(por. Abramowicz 2010, 36).

Okres stalinowski miał oczywiście nie tylko takie, groteskowe oblicze.

Studiom Zbigniewa Romka zawdzięczamy wyjaśnienie kwestii wieloletniego opóźnienia druku pracy na temat wyprawy Włodzimierza z 981 r., autorstwa Stefana Marii Kuczyńskiego(1904-1985). Praca ta była w zasadzie gotowa już w 1949 r., ukazała się jednak wiele lat później (Kuczyński 1965).
Stało się tak ze względu na objęcie jej zakazem publikacji. Zadecydowała tu negatywna opinia Stanisława Arnolda (1895-1973) i Juliusza Bardacha (1914-2010), zdaniem których praca zdradzała elementy „prowatykańskie”, dowodziła polskości ziem nad środkowym Bugiem, a nawet Wołynia, a także służyć miała Kuczyńskiemu ,[...] do przemycania pod dobrosąsiedzką flagą bagażu nacjonalistycznych obciążeń burżuazyjnej nauki polskiej” (Romek 2010, 177-181 [tu obszerne cytaty z wszystkich recenzji]). Nie pomogły tu pozytywne opinie Gerarda Labudy (1916-2010), A. Gieysztora czy Henryka Łowmiańskiego (1898-1984). S. M. Kuczyńskibyłuczniem OskaraHaleckiego(1891-1973; na temat Haleckiego zob. Dąbrowska [red.] 2012; 2014a; 2014b; na temat jego uczniów, w tym Kuczyńskiego zob. Kozłowski 2014, 57-58), historyka zdecydowanie źle ocenianego w stalinowskiej Polsce - zapewne ten fakt dodatkowo przyczynił się do blokady publikacji Kuczyńskiego.

Poniżej zdecydowano się zaprezentować jedynie kilka uwag dotyczących badań nad Grodami Czerwieńskimi w latach 50-tych XX w.

Frapującym jest problem ich genezy, jak i charakteru - tego, na ile były to badania polsko-radzieckie.

W sporej liczbie tekstów związanych z tymi pracami mowa jest o badaniach polsko-radzieckich, tak przedstawiał je np. w krótkim eseju na łamach Przekroju Paweł Jasienica (Lech Beynar; 1909-1970) - historyk, dziennikarz uczestniczący w pracach wykopaliskowych (Jasienica 1952). Również w dokumentach, tekstach sporządzonych przez naukowców mowa jest o badaniach polskoradzieckich, wielokrotnie pojawia się kwestia konieczności intensyfikacji kontaktów z badaczami radzieckimi. Jako polsko-radzieckie określono badania już w dokumencie z 17-go V 1952 r., w którym A. Gieysztor zwraca się do Ministerstwa Szkolnictwa Wyższego z prośbą o zaliczkę celem rozpoczęcia badań terenowych (por. Gieysztor zaliczka 1952). Nadzieję na przyjazd gości radzieckich wyraża kilku uczestników narady, jaka miała miejsce w Hrubieszowie dnia 28 VIII 1952 r. (por. Notatka służbowa 1952). W referacie wygłoszonym w Lublinie 20 V 1952 r. Henryk Łowmiański rozdział końcowy swego wystąpienia poświęcił w całości uzasadnieniu konieczności nawiązania jak najściślejszej współpracy polsko-radzieckiej w badaniach Grodów Czerwieńskich (Łowmiański 1953, 84-85). 
Najwyraźniej podkreślanie związków z nauką radziecką widoczne jest w referacie W. Antoniewicza, zatytułowanym Uwagi o badaniach Grodów Czerwieńskich w r. 1952, jaki wygłosił on w trakcie konferencji w Hrubieszowie we wrześniu 1953 r. Swoje wystąpienie Antoniewicz rozpoczął w następujący sposób:

Może nie od rzeczy będzie wspomnienie na wstępie o dotychczasowych zamierzeniach prowadzenia systematycznych badań archeologicznych na Grodach Czerwieńskich. Pierwsze tego rodzaju usiłowania rozpoczęła z ramienia Zakładu Archeologii Przedhistorycznej i Wczesnodziejowej Uniwersytetu Warszawskiego w r. 1936 Zofia Wartołowska. Ówczesne możliwości finansowe na cele prac wykopaliskowych byty bardzo nikłe; toteż program badań z konieczności musiat sie zacieśnić tylko do jednego grodziska w Sasiadce w pow. Zamość. Przed wojna badania te byty prowadzone przez cztery lata; $w$ Polsce Ludowej zaś, dzięki właczeniu prac wykopaliskowych w Sasiadce do budzetu państwowego $w$ dziale Uniwersytetu Warszawskiego, badania te rozwijaja się pomyślnie dalej rok rocznie od r. 1946. Prace wykopaliskowe na grodzisku w Sasiadce sa prowadzone nader szczegótowo, wpierw na obszarze t. zw. gródka, a obecnie na obszarze t. zw. podgrodzia. Sa to najbardziej zaawansowane dotad badania systematyczne jednego z Grodów Czerwieńskich.

Podczas wojny, w r. 1942, prowadzit z ramienia władz niemieckich badania sondażowe na grodzisku i na cmentarzysku opodal grodziska w Czermnie (pow. Tomaszów) archeolog ukraiński Dr. L. Czikalenko. Zabytki uzyskane $w$ czasie tych poszukiwań byty zdeponowane w Muzeum w Chetmie.

$\mathrm{Na}$ kilku konferencjach Kierownictwa Badań nad Poczatkami Państwa Polskiego w l. 19481951, referowatem duza potrzebę konieczności zorganizowania systematycznych badań Grodów Czerwieńskich w porozumieniu z radzieckimi uczonymi. W tym temacie prowadzitem w l. 1949-51 rozmowy z prof. Tretiakowem $i$ prof. Rybakowem, którzy jak najzyczliwiej traktowali te projekty. Podczas konferencji roboczej Kierownictwa Badań n. p. P.P. z prof. Rybakowem w r. 1950, po referacie Wt. Antoniewicza, przedstawiła Dr Z. Wartołowska krótkie sprawozdanie z prac wykopaliskowych $w \mathrm{Sa}$ siadce oraz propozycję rozpoczęcia wspólnych badań polsko-radzieckich na Grodach Czerwieńskich. Na skutek zaś zainteresowania się $w$ grudniu r. 1951, podczas konferencji historyków polskich w Otwocku, przez profesorów Griekowa i Tretiakowa koniecznościa podjęcia badań Grodów Czerwieńskich równocześnie na terytorium Polski i Zwiazku Radzieckiego zapadła wówczas decyzja przystapienia do organizacji tych prac wykopaliskowych na naszym obszarze. [...]. Dzięki dotacji Prezydium Rzqdu Polski Ludowej, w kwocie pót miliona złotych, można byto łatwo postawić organizację badań Grodów Czerwieńskich na wysokim poziomie. Po licznych czynnościach przygotowawczych rozpoczęto prace wykopaliskowe w Gródku $w$ drugiej połowie sierpnia 1952 r., a zakończono je z poczatkiem października ub. $r$.

Jako bazę badawczq wybrało kierownictwo badań Hrubieszów; i uzyskano tam w koszarach W.P. wygodne pomieszczenie na kwatery personelu naukowego, technicznego, administracyjnego, oraz na pracownie naukowe i techniczne. Ekspedycja obejmowała około 100 osób, byta ona dobrze i sprawnie zorganizowana w Hrubieszowie

(por. Antoniewicz, Uwagi...1952).

W świetle mego rozeznania badania z lat 19361939 nie były zamierzone jako wstęp do badań nad Grodami Czerwieńskimi czy pograniczem polskoruskim, istotnym było rozpoznanie grodziska jako takiego. Jak wiadomo, Z. Wartołowska i W. Antoniewicz interesowali się tą kategorią źródeł w skali całego kraju (por. Antoniewicz, Wartołowska [red.] 1964). W archiwaliach Antoniewicza, przechowywanych w PAN, nie znalazłem dokumentów poświadczających jego zaangażowanie w organizację polsko-radzieckich badań nad pograniczem polskoruskim $^{17}$.

Oczywiście, częste pojawianie się przymiotnika ,radziecki” w tekstach z okresu stalinowskiego nie dotyczy jedynie archeologii. Informacje o współpracy polsko-radzieckiej nie muszą dotyczyć realnie odbywających się prac, a stanowić skutek ówczesnej nachalnej propagandy (por. Behrends 2006).

17 Co niekoniecznie musi być rozstrzygające - trudno mi określić kompletność archiwum Antoniewicza w PAN, poza tym listy tego badacza mogą znajdować się jedynie $\mathrm{w}$ archiwach pozostawionych przez adresatów korespondencji. 
Wydaje się, iż zwłaszcza w wypadku W. Antoniewicza podkreślanie starań o wspólne, polskoradzieckie badania wpisuje się w całość strategii, jaką badacz ten przyjął po II wojnie światowej. Jak pisze J. Lech:

Obok W. Holubowicza byt [Antoniewicz M.W.] najbardziej ofensywnym marksista $w$ okresie stalinowskim, krytykujacym $z$ tych pozycji swoich kolegów, w tym powszechnie szanowanych przedstawicieli środowiska naukowego. Powstaje pytanie, czy musiat tak postępować? Można przypuszczać, że istotna role odgrywały tu obciażenia z przeszłości, obawa o oskarżenie o postawe 'w latach sanacji', o getto lawkowe $w$ Uniwersytecie Warszawskim, o wspótpracę z W. Radigiem i Instytutem Niemieckiej Pracy Wschodniej [...]

(por. Lech 2009, 200).

Tak jak słynne - i niechlubne - studium Dotychczasowy dorobek archeologii Polski (Antoniewicz 1953) miało być świadectwem pełnego nawrócenia Antoniewicza na marksizm, tak podkreślanie gotowości do współpracy z naukowcami radzieckimi, datowanie początków badań nad Grodami Czerwieńskimi już na rok 1936 (a tym samym przypisanie sobie i swoim współpracownikom inicjatywy w tej dziedzinie) wydaje się być kolejnym elementem strategii, która miała umożliwić odnalezienie się w stalinowskiej Polsce byłemu rektorowi Uniwersytetu im. J. Piłsudzkiego ${ }^{18}$.

W rzeczywistości udział badaczy radzieckich w badaniach Grodów Czerwieńskich był minimalny i sprowadzał się do kurtuazyjnych wizyt, jak wspomniana Arcichowskiego w 1953 r. Nigdy nie doczekano się na badania stanowisk po wschodniej stronie Bugu (pisał o nich m.in. wspomniany już P. Jasienica). Polsko-radzieckość interesujących nas badań jest więc w dużej mierze produktem epoki, w której realizowano - de facto polskie - prace wykopaliskowe w Czermnie, Gródku czy Sąsiadce ${ }^{19}$.

18 Warto w tym miejscu przypomnieć, że w 1945 r. Antoniewicz musiał ustapić ze stanowiska rektora Uniwersytetu Warszawskiego i stanął przed Komisją Dyscyplinarną UW, która uniewinniła go dopiero 1948 r.; por. Kozłowski 2004, 177.

19 W tym kontekście przedstawić należy koncepcję Tadeusza Rutkowskiego, który inicjatywę prac nad Grodami Czerwieńskimi postrzega przez pryzmat osobistej sytuacji Gieysztora. Sukcesy w pracy w ramach Kierownictwa Badań nad Początkami Państwa Polskiego miały spowodować ,[...] że pochodzenie klasowe i AK-owska
Warto w tym miejscu choć kilka słów poświęcić jeszcze Borysowi Grekowowi, bezwzględnie najważniejszemu radzieckiemu mediewiście bezpośrednio po II wojnie światowej, a zarazem jednemu z przewodniczących delegacji radzieckiej na konferencji metodologicznej w Otwocku (1951/1952), w trakcie której miano zadecydować o podjęciu badań nad Grodami Czerwieńskimi.

Przyjazd Grekowa do Otwocka nie był oczywiście przypadkowy - istotny był tak jego dorobek naukowy, jak i znajomość języka polskiego - od 1910 r. przez cztery lata Grekow studiował na Wydziale Historyczno-Filologicznym Uniwersytetu Warszawskiego (studia kontynuował w Moskwie). $\mathrm{Z}$ rozpatrywanego tu punktu widzenia szczególnie interesujący jest jeszcze jeden szczegół z biografii Grekowa: przyszły mediewista, choć urodził się w głębi rosyjskiego imperium (Myrhorod [Миргород] nieopodal Połtawy), to jednak w latach 90-tych XIX w. mieszkał przez kilka lat w Chełmie i Hrubieszowie (por. Gorskaja 1999, 20-22; Szumski 2016, 70-71). Nazwy niewielkich przecież rzek jak Huczwa ${ }^{20}$, Wieprz pojawiają się w jego - przywołanym już - referacie wygłoszonym w październiku 1939 w Moskwie. Nie można więc wykluczyć, iż propozycja prac nad Grodami Czerwieńskimi mogła przypaść mu do gustu także $\mathrm{z}$ osobistych powodów.

Ważne jest także, iż w trakcie konferencji w Otwocku Grekow wyraźnie studził zapał polskich marksistów-dogmatyków żądających bły-

przeszłość nie załamały kariery młodego uczonego, choć z całą pewnością w okresie rozwiniętego stalinizmu (19491955) musiały powodować poczucie ciagłego zagrożenia i niepewności" (Rutkowski 2013, 142). Zdaniem warszawskiego badacza: „Pozycję Gieysztora w najgorszym okresie stalinowskim wzmocniła nawiązana przez niego na przełomie 1951 i 1952 roku w trakcie I Konferencji Metodologicznej Historyków Polskich współpraca z uczonymi sowieckimi, której efektem było rozpoczęcie wiosną $1952 \mathrm{r}$. przez KBnPPP wykopalisk na terenach dawnych Grodów Czerwieńskich, przy granicy polsko-sowieckiej. Paradoksalnie spowodowały one jednocześnie zwiększenie zainteresowania funkcjonariuszy MBP osobą Gieysztora. W październiku 1952 r. w piśmie do dyrektora Gabinetu Ministra BP dyrektor Departamentu III, płk Józef Czaplicki wyraził pogląd, że Gieysztor 'nie powinien otrzymać zezwolenia na prowadzenie prac naukowych w strefie granicznej"”, por. Rutkowski 2013, 142.

20 Nad Huczwą leży tak Hrubieszów, jak i Czermno oraz Gródek. 
skawicznej stalinizacji nauki polskiej ${ }^{21}$ i starał się chronić - dziś powiedzielibyśmy - źródłoznawców, np. Tadeusza Manteuffla (1902-1970). Jak pisze Jan Szumski:

Po pierwsze, wydaje się, że Grekow pragnat nie dopuścić do zwycięstwa dogmatyków, dobrze wiedzac z własnego gorzkiego doświadczenia $^{22}$,jakie moga być tego skutki. Po drugie, przebudowa nauki historycznej na wzór sowiecki przewidywała tolerowanie, przynajmniej na poziomie formalno-deklaratywnym, uczonych 'starej daty', niestojacych na stanowisku dogmatycznego marksizmu, czego przykładem byt sam Grekow [...]

(por. Szumski 2016, 166).

Reasumując: nie można wykluczyć, iż propozycja Gieysztora zmierzająca do podjęcia wspólnych polsko-radzieckich badań nad Huczwą i Bugiem mogła spotkać się z życzliwym zainteresowaniem Grekowa z powodów pozamerytorycznych.

Trudno na zakończenie nie wspomnieć o ujmującej osobowości warszawskiego mediewisty. Urodzony w Moskwie Gieysztor nadawał się jak nikt inny jako partner dla radzieckiego mediewisty (na temat związków A. Gieysztora z nauką i kulturą rosyjską zob. Grala 2016, zwł. 37-42).

$* * *$

Badania z lat 1952-1955 przyniosły bardzo ciekawe rezultaty, zostały jednak zarzucone, a ich wyników nigdy nie opublikowano w całości, dotyczy to zwłaszcza rezultatów prac w Gródku.

Pół wieku później T. Dunin-Wąsowicz z goryczą wspominała, iż

21 Jak pisze Z. Romek (2002, 96): „Na konferencji tej [w Otwocku - M.W.] przedstawiciele polskich władz i polscy historycy uroczyście ogłosili, że za naukową można uznać jedynie metodologię marksistowską. W kolejnych referatach uczeni przedstawiali jak nowe metody stosować w analizie kolejnych fragmentów dziejów Polski. Jako obowiązującą w praktyce badawczej uznano zasadę partyjności nauki, w myśl której historycy winni realizować wytyczne ideologów".

22 W 1951 r. Grekow, oskarżony o kosmopolityzm i obiektywizm burżuazyjny, stracił stanowisko dyrektora Instytutu Słowianoznawstwa AN ZSRR, w 1953 stracił zaś posadę dyrektora Instytutu Historii AN ZSRR. Wydarzenia te przyczyniły się do jego śmierci jesienią 1953 r.; por. Szumski 2016, 152-153, 163.
Zmarnowane sa prace wykopaliskowe, rozpoczęte przed wojnq $w$ Sasiadce [...] bezpowrotnie zmarnowano część badań pochodzacych z Grodów Czerwieńskich, które mogły być 'złotym jabłkiem'dla archeologów polskich (por. Dunin-Wasowicz 2000, 251-251).

Czermno i Gródek to - rzecz jasna - nie jedyne nieopublikowane wczesnośredniowieczne stanowiska w Polsce, powody załamania się tamtejszej akcji wykopaliskowej od dawna budzą jednak duże zainteresowanie. Przyczynił się do tego A. Abramowicz, uczestnik, a po latach także kronikarz czermieńskiej ekspedycji z 1952 r. W swej historii polskiej archeologii łódzki badacz stwierdził m.in. iż

Wśód archeologów odczuwano wtedy [w trakcie badań w Czermnie - M.W.] niepokój czy badania te nie sq jakimś wstepem do korekty granicy na wschodzie

(por. Abramowicz 1991, 159).

Poniżej postanowiono odnieść się nieco szerzej do tej kwestii, zwłaszcza, iż sugestia Abramowicza powtarzana jest $\mathrm{w}$ dalszych opracowaniach (por. Kobyliński 2007, 369).

Powojenna granica Polski (od 1952 r. Polskiej Rzeczpospolitej Ludowej) określana była umowa z dnia 16-go VIII 1945 pomiędzy rządem RPi ZSRR (por. Bartoszewicz 1995; Wawryniuk 2015, 394). Jak dość powszechnie wiadomo, w maju 1951 r., w odpowiedzi na propozycję strony radzieckiej doszło do korekty granicy obu państw: Polska utraciła Bełz, natomiast uzyskała Ustrzyki Dolne (Smoleń 2004; Wawryniuk 2015, 394-424).

Z dokumentów opublikowanych już po $1989 \mathrm{r}$. (Tebinka 1994) wynika, iż w drugiej połowie $1952 \mathrm{r}$. Moskwa $^{23}$ sformułowała propozycje kolejnej cesji terytorium PRL. Tym razem na rzecz ZSRR stracilibyśmy m.in. Hrubieszów oraz Tomaszów Lubelski. Granica państwowa biegłaby wzdłuż rzeki Huczwy, w tej sytuacji grodzisko w Gródku znalazłoby się po stronie ZSRR, natomiast umocnienia w Czermnie leżałyby dosłownie na linii granicznej (Wawryniuk 2015, rycina na s. 426). Do realizacji tych planów nie doszło, najpewniej na wskutek śmierci Stalina 5 III 1953 r. (Tebinka 1994; Wawryniuk 2015, 424-428).

23 Dokument nie posiada jasno określonego nadawcy, ani daty, jak stwierdza Andrzej Wawryniuk: „Najprawdopodobniej - jak to było w ówczesnym zwyczaju - wręczył go polskim władzom jako propozycję ambasador ZSRR w Polsce"; por. Wawryniuk 2015, 424, przyp. 224. 
Czy sformułowana jesienią 1952 r. propozycja korekty granicy polsko-radzieckiej mogła przyczynić się do wstrzymania badań nad Grodami Czerwieńskimi, zgodnie z sugestią A. Abramowicza? Wydaje się, iż możliwość taką należy wykluczyć. Wskazać tu należy co najmniej na dwa fakty:

1). oficjalnym powodem wymiany terytorialnej z 1951 r. były względy gospodarcze, nie sformułowano wówczas żadnych argumentów odwołujących się do historii czy specyfiki kulturowej wymienianych regionów;

2). mimo iż wymiana terytorialna z $1951 \mathrm{r}$. była oficjalnie określana aktem braterskiej pomocy ze strony Stalina, to ostatecznie wywołała ona falę niepokojów w całym kraju.

Kluczowa jest druga z przytoczonych obserwacji. Już ponad dwie dekady temu Dariusz Jarosz wskazał na wybuch prawdziwej paniki związanej z informacją o ,korekcie” granicy PRL-ZSRR z 1951 r. (Jarosz 1993).

W archiwum PZPR, przechowywanym obecnie w Archiwum Akt Nowych w Warszawie, znajdują się m.in. raporty na temat nastrojów ludności w związku ze wspomnianym wydarzeniem. Były one fatalne, tak na wschodzie kraju, jak i w dalszych jego częściach. I tak w 1951 na terenie powiatu tomaszowskiego ,[...] w nocy z 29 - 30 maja br. zatrzymano 20 furmanek, które wywoziły sprzęt domowy na inne tereny" (por. Informacja... I). Na terenie ówczesnego województwa szczecińskiego:

Sa również wypowiedzi [pow. Myślibórz] że wymiana jest niekorzystna dla Polski, gdyż przekreśla linię Curzona, a tym samym nienaruszalność granic na Odrze i Nysie. Kraża również plotki, że ludność z terenów objętych wymianq wywożona jest przez NKWD na Ural i Syberie (Informacja... II).

Szczególnie plastycznie odmalowano sytuację, jaka miała miejsce na Dolnym Śląsku. Jak stwierdza - 26 V 1951 - anonimowy informator:

23 b.m w internacie SPP przy Zakładach im. 22 Lipca $w$ Dzierżoniowie, podczas czytania artykułu $w$ sprawie wymiany odcinków granicznych między Polska a ZSRR, jedna z dziewczat - Wolska - powiedziała, ze jest to rabunkowa gospodarka w stosunku do nas ze strony ZSRR, że ZSRR pomału cała Polskę zabierze. Zdanie Wolskiej poparty i inne dziewczęta. Wówczas Wolska zrzucita miotta ze ściany portret jednego z dostojników rzqdu. [...] Dopiero po przeprowadzonych przez sekretarza ppp [...] indywidualnych rozmowach, dziewczęta zrozumiaty, że popetnity bład i okazaty skruche (por. Informacja... III).

Wymiana graniczna z 1951 r. była prawdziwą klęską wizerunkową dla PZPR, z całą pewnością ówczesne władze zdecydowały się utajnić nową propozycję Wielkiego Brata. Trudno zakładać, iż wyjątek uczyniono dla archeologów.

Warto może zastanowić się, czy odpowiedzialności za rozpowszechnienie obaw o związku prac wykopaliskowych z korekta granicy nie ponoszą... sami archeolodzy (oczywiście nieświadomie). Zwłaszcza ekipa łódzka, kierowana przez K. Jażdżewskiego ubrana była w stroje wojskowe, czy też para-wojskowe, poruszała się także wojskową ciężarówką. Z oczywistych powodów dysponowała ona także urządzeniami mierniczymi. O tym, że podwładni Jażdżewskiego mogli sprawiać wrażenie grupy wojskowych, najlepiej świadczy epizod opisany przez A. Abramowicza:

Któregoś wieczoru w Czermnie, akurat miałem jedna noge w miednicy, ustyszałem ciche głosy na zewnatrz, a potem ktoś gwattownie wtargnat do naszej izby. Bytem z boku i w pierwszej chwili nie widziatem, co się stało. Rzut oka i zrozumiatem. To milicjant wszedt z takim rozpędem i zdrętwiat. Andrzej Nadolski mówit potem, że dawno nie widziat kogoś tak pobladtego. Łatwo byto odgadnać powód. Rzędem pod ścianq leżaty śpiwory na siennikach, na ścianie wisiaty chlebaki, kurtki koloru ochronnego, lornetka, w kacie stat trójnóg teodolitu. Oczywiście jakaś grupa partyzancka, dywersyjna lub bandycka. Sami mężczyźni. Karbowiak już utożyt się do snu w swoim śpiworze. Milicjant pierwsza odzywka kazał mu wyjać na wierzch ręce. Po chwili ostupienia doszło do wyjaśnień. Okazało się, że miejscowa milicja (posterunek byt daleko) otrzymała informacje, że obcy kręca się po okolicy i że nocuja. Przyszła sprawdzić ktoto

(por. Abramowicz 2010, 19).

Moim zdaniem nie można wykluczyć, iż obawy związane ze zmianą granicy, jakie wywołały decyzje z 1951 r., odżyły w Czermnie w 1952 r. za sprawą - pracujących nad granica, ubranych ,po wojskowemu", korzystających $\mathrm{z}$ geodezyjnego sprzętu mierniczego - archeologów, których wypytano o charakter prowadzonych prac i o ewentualną zmianę granicy. 
Szczegółowe wyjaśnienie przyczyn, dla których zaniechano realizacji badań na terenie Grodów Czerwieńskich, możliwe będzie jedynie przy kontynuacji dalszych badań archiwalnych. Już teraz wskazać można na powody bardziej ogólnej natury, które mogły prowadzić do załamania się tej akcji.

Wspomnieć tu należy o niechętnym stosunku społeczeństwa (w tym naukowców) do ZSRR, a przede wszystkim do wymuszonej współpracy z Wielkim Bratem ${ }^{24}$. Trudno nie wspomnieć o znacznym sformalizowaniu (zrytualizowaniu) kontaktów z przedstawicielami Kraju Rad, o nieznośnym gorsecie politycznej kontroli (por. Romek 2002; Szumski 2016, 332). Warto także zauważyć, iż dla legitymizacji władz PRL istotnym było podkreślanie nie tylko umocowania zachodniej granicy Polski na Odrze i Nysie, ale i korzystnych aspektów utraty tzw. Kresów. Machina propagandowa PRL nie szczędziła środków dla uzasadnienia naszych „odwiecznych” praw do Szczecina czy Wrocławia (Kobyliński, Rutkowska 2005; Dmitrów 2009). Równie słuszna była wschodnia grani-

24 Jeden $\mathrm{z}$ prowadzących badania - K. Jażdżewski - pisał: „Między połową sierpnia a końcem września 1952 r. stałem się trochę 'po niewoli' współuczestnikiem oryginalnej imprezy archeologicznej, mianowicie wypadło mi brać udział w badaniach Grodów Czerwieńskich. [...] w Kierownictwie Badań nad Początkami Państwa Polskiego wywarto na mnie nacisk, abym włączył się do tej akcji. Rzecz była ponoć pomyślana jako fragment współpracy archeologów polskich i radzieckich przy badaniu wzajemnych kontaktów polsko-ruskich we wczesnym średniowieczu. Niewzięcie udziału w tej imprezie mogło - jak mi mówiono - być poczytane za bojkotowanie tej współpracy. [...] Z pobytu w Gródku Nadbużnym zachowałem wspomnienie, wiążące się z oglądaniem z góry - z wyżyn płaskowzgórza - urządzeń i zabiegów mających zabezpieczyć mołotowsko-ribbentropowską i jałtańską granicę między PRL i ZSRR, przebiegającą wzdłuż Bugu. Jakież dziwne myśli i uczucia miało się, gdy patrzyło się na ten pusty pas ziemi wzdłuż rzeki po sowieckiej stronie, co dzień na nowo bronowany, by na nim móc odczytać ewentualne ślady stóp ludzi uciekających z 'przodującego' państwa 'socjalistycznego' na stronę polską, bardzo słabo pilnowaną. [...] Mówiono nam, że w ciągu długiego czasu zdarzył się raz tylko wypadek, że z Polski uciekł ktoś na stronę sowiecką. Przy badaniu ujętego tam zbiega okazało się, że był on umysłowo chory. Zwrócony Polsce ponawiał podobno próby przedostania się na wschód na drugą stronę z maniackim jakimś uporem. Kto wie - może gnała go nieprzezwyciężona nostalgia do stron rodzinnych, od których odcięto go na skutek IV rozbioru Polski, dokonanego we wrześniu 1939 r.?”; por. Jażdżewski 1995, 266-267. ca PRL, rzekomo wytyczona wzdłuż sprawiedliwej linii Curzona. Przypominanie o znaczeniu kultury polskiej dla ziem na wschód od owej linii nie było preferowanym tematem badawczym. Równocześnie - i to z naszego punktu widzenia jest najistotniejsze - mówienie o elementach prawosławnych, ruskich we wschodniej części dzisiejszej Polski nie odpowiadało wizji PRL szczęśliwie wybawionej przez Stalina i polskich komunistów - od koszmaru mniejszości etnicznych czy religijnych. Najlepszym, acz smutny dowodem na to jest los drewnianych cerkiewek w Polsce południowo-wschodniej (Losy cerkwi...1997) ${ }^{25}$

W dłuższej perspektywie kluczowe wydają się jednak przemiany cywilizacyjne będące skutkiem II wojny światowej. Od 1945 r., w rezultacie utraty Lwowa oraz Wilna, brak w Polsce na wschód od Wisły dużych ośrodków naukowych, muzealnych. Intrygującym jest pytanie, dlaczego w okresie PRL nie stworzono tu ani jednego ośrodka Instytutu Historii Kultury Materialnej PAN. Ani powstały w 1945 r. Instytut Archeologii na lubelskim UMCS, ani powstały w 1999 r. Instytut Archeologii na Uniwersytecie Rzeszowskim nie były w stanie zasypać

25 W tym kontekście wspomnieć należy o powojennych, napiętych relacjach polsko-ukraińskich, istotna jest tu zarówno tzw. rzeź wołyńska, jak i akcja Wisła; por. na ten temat Motyka 2011.

Osobny problem to ukraińskie roszczenia terytorialne względem dzisiejszej wschodniej Polski. Już pod koniec II wojny światowej Stalin szantażował Mikołajczyka przypominaniem problemu tzw. Zakerzonia, a więc ukraińskich aspiracji do władzy nad Chełmem, Przemyślem. Zależność polityczna od Moskwy w latach 1944-1989 decydowała o tym, że kwestia ta nie traciła na znaczeniu także po śmierci Stalina. Trudno przedstawiać tutaj ten problem szerzej, warto jednak zacytować Włodzimierza Mędrzeckiego, piszącego o współczesnej dyskusji polskich i ukraińskich historyków: „W aksjologii ukraińskiej [...] Chełmszczyzna, Podlasie łącznie z Bielskiem Podlaskim, Łemkowszczyzna po Krynicę w sposób niepodlegający dyskusji są częścią Ukrainy, nawet jeśli pozostają poza jej granicami” (Mędrzecki 2010, 47).

Polscy archeolodzy, zwłaszcza ci ze szkoły Kostrzewskiego, jak np. Jażdżewski, byli przyzwyczajeni do wykorzystywania słowiańskich zabytków jako argumentu za polskością Śląska czy Pomorza, otwartym pozostaje pytanie, na ile ruski charakter zabytków odkrywanych w Czermnie czy Gródku mógł budzić ich niepokój, gdyż postrzegali je jako potencjalny argument na rzecz proukraińskiej „korekty” wschodniej granicy Polski. 
wyrwy powstałej w $1945 \mathrm{r}$. Nikt też nie powrócił do idei lwowskiego Muzeum Ziemi Czerwieńskieje'

Po załamaniu się akcji wykopaliskowej z lat 50-tych XX w. nie sformułowano w okresie PRL żadnego większego planu archeologicznych badań nad pograniczem polsko-ruskim. Odnotować należy opracowanie Andrzeja Nowakowskiego (1939-2017; por. Nowakowski 1972), który jednak w ograniczonym zakresie mógł wykorzystać - nieopublikowane - wyniki badań w Gródku czy Sąsiadce.

W latach 1976-1979 miały miejsce - zakrojone na szeroką skalę - badania w Czermnie pod kierunkiem Jana Gurby. Mimo ukazania się całej serii komunikatów, sprawozdań wyniki badań z lat 70-tych i 80-tych XX w. w Czermnie pozostawały do niedawna właściwie nieznane, przy czym tym razem - co chciałbym wyraźnie podkreślić - odpowiedzialnością za ten fakt nie da się obarczyć ani Historii, ani nawet Moskwy. Przebieg prac zespołu J. Gurby, sposób potraktowania zabytków, brak publikacji źródłoznawczych są smutnym dowodem na braki logistyczne ośrodka, który podjął tę próbę. Katedra/Zakład/Instytut Archeologii UMCS, będąc zawsze ,[...] najmniejszą instytucją archeologii uni- wersyteckiej w Polsce" (Kokowski, Łuczkiewicz 2016, 122), w oczywisty sposób nie mógł sprostać wyzwaniom związanym z badaniami tak bogatego w znaleziska archeologiczne stanowiska.

Od lat 80-tych XX w. narastać zaczął problem rabunku regionu Grodów Czerwieńskich, jak melancholijnie stwierdził zamojski archeolog - Jerzy Kuśnierz:

Stawne grody wydane zostały na pastwe zbieraczy i rabusiów starożytności, wyposażonych $w$ nowoczesne detektory metali, siejacych zniszczenie na obiektach przy biernej postawie stużb konserwatorskich [...]

(por. Kuśnierz 2003, 22).

W 1997 r. pobrano m.in. z wału grodziska w Czermnie próby drewna. Fakt, iż pochodziły one z drzewa ściętego w XI w. (Gurba, Urbański 1998), stał się przyczyną powątpiewania części archeologów, ale i historyków w zasadność identyfikacji Czermna z latopisowym grodem Czerwień (por. np. Tyszkiewicz 2004, 195). Równocześnie narastała świadomość fatalnego wręcz stanu badań nad wczesnym średniowieczem $\mathrm{w}$ tym regionie Polski (por. zwłaszcza Kowalczyk 2000b, 56; Poleski 2004, 386-387).

\section{ZAKOŃCZENIE}

Upadek systemów totalitarnych w naszej części Europy, zapoczątkowany zwycięstwem Solidarności w wyborach 4 VI 1989 r., wyznacza oczywistą cezurę także w dziejach polskiej archeologii, w tym w badaniach Polski wschodniej (por. Wołoszyn w druku).

Stopniowo, badania pogranicza polsko-ruskiego zaczęły nabierać tempa. Trudno tu nie wspomnieć opracowania Michała Parczewskiego o początku polsko-ruskiego pogranicza (Parczewski 1991), ani konferencji na temat początków sąsiedztwa w naszej części Europy (Czopek, Parczewski [red.] 1996). W połowie lat 90-tych XX w. - dzięki Andrzejowi Buko - zaczął formować się międzynarodowy i interdyscyplinarny zespół zmierzający do kompleksowego rozpoznania Chełma i pobliskiego Stołpia (por. ostatnio Buko, Gołub [red.] 2016).

26 W tym kontekście istotna jest także marginalizacja Lwowa i tamtejszej archeologii po 1945 r.; por. Sytnyk 2006.
Od ok. 2008 r. realizowane są prace zmierzające do nadrobienia zaległości w rozpoznaniu Czermna i Gródka (por. Sikora, Wołoszyn 2011).

Wspaniałe odkrycia dokonane w Czermnie w latach 2010-2011 przez archeologów z UMCS (por. Bagińska et al. [red.] 2012), w tym dwa skarby (XIII-XIV w.), dowiodły, iż opracowanie całościowego planu badań nad tym stanowiskiem stało się naprawdę pilnym zadaniem.

Obecnie w badania nad Grodami Czerwieńskimi zaangażowane jest już kilkadziesiąt osób, prace naszego zespołu finansowane są tak ze źródeł polskich (Ministerstwo Nauki i Szkolnictwa Wyższego w ramach Narodowego Programu Rozwoju Humanistyki oraz Narodowe Centrum Nauki), jak i niemieckich (Bundesministerium für Bildung und Forschung, od 2017 Leibniz-Gemeinschaft), biorą w nich udział badacze z Polski, Niemiec, Rosji, Serbii, Szwajcarii oraz Ukrainy (por. Wołoszyn 2016a).

Wyniki dawnych (do 2010) prac wykopaliskowych na terenie Czermna opublikowano ostatnio w postaci dwutomowej monografii (por. Florek, 
Wołoszyn [red.] 2016). W tym roku winno ukazać się podobne opracowanie dotyczące Gródka. W ramach opracowywania pozyskanych już w Czermnie i Gródku źródeł prowadzone są nie tylko tradycyjne badania, wykorzystujemy możliwości współczesnej antropologii czy nauk technicznych.

Tym niemniej oczywistym jest, iż dla pełnego poznania dziejów Grodów Czerwieńskich konieczne są wieloletnie prace terenowe. W Czermnie prace wykopaliskowe rozpoczęto w 2013 r., ich wyniki przyjmowane są $\mathrm{z}$ dużym zainteresowaniem (por. np. Poleski 2017, 76, przyp. 148) ${ }^{27}$. Mam nadzie-

27 Dzięki badaniom z lat 2014-2016 jasne jest np., że drewno pobrane z wału w Czermnie w 1997 r. nie wiąże się $\mathrm{z}$ najstarszą fazą umocnień. ję, że od 2018 r. badania terenowe obejmą także Gródek.

Oba stanowiska położone są z dala od większych osiedli. Jedynym realnym sposobem ograniczenia ich rozgrabiania jest przekształcenie całych kompleksów osadniczych w Czermnie i Gródku w skanseny - obecnie podejmowane są kroki zmierzające $\mathrm{w}$ tym kierunku.

Zamykając powyższy esej, chciałbym wyrazić przekonanie, iż tak Czermno, jak i Gródek dostarczą jeszcze wielu fantastycznych zabytków związanych z formowaniem się pogranicza polsko-ruskiego i nadzieję, że wysiłki międzynarodowego, interdyscyplinarnego zespołu, którym mam zaszczyt kierować, uczynia jeszcze $\mathrm{z}$ regionu nad środkowym Bugiem złote jabłko polskiej archeologii.

\section{BIBLIOGRAFIA}

\section{Skróty}

AAN Archiwum Akt Nowych.

PAN Polska Akademia Nauk.

PMA Państwowe Muzeum Archeologiczne.

\section{Źródła archiwalne}

Antoniewicz, Uwagi...1952. W. Antoniewicz, Uwagi o badaniach Grodów Czerwieńskich w r. 1952; rękopis oraz maszynopis w Archiwum PAN, Warszawa, Materiały W. Antoniewicza, sygnatura III.22.

Czykałenko, list 1940. L. Czykałenko, list do Z. Wartołowskiej z 16-go VIII 1940 r.; maszynopis w Archiwum PMA, Warszawa.

Drewko, list 1947. M. Drewko, list do S. Noska z 3-go XII 1947; maszynopis w Archiwum PMA, Warszawa.

Gieysztor, notatka 1952. A. Gieysztor, notatka służbowa z 10-go I 1952 r. w sprawie wspólnych badań archeologicznych polsko-radzieckich na obszarze Grodów Czerwieńskich; maszynopis w archiwum Muzeum Zamojskiego w Zamościu.

Gieysztor, zaliczka 1952. A. Gieysztor, pismo do Ministerstwa Szkolnictwa Wyższego z 17-go V 1952 r. z prośbą o zaliczkę celem rozpoczęcia badań terenowych na obszarze Grodów Czerwieńskich; maszynopis w archiwum Muzeum Zamojskiego w Zamościu (pismo Kierownictwa Badań nad Początkami Państwa Polskiego, nr Z-VIII-63b/31-23/52).
Informacja I. Informacja. Po umowie $w$ sprawie wymiany odcinków przygranicznych (maszynopis), AAN (PZPR, Komitet Centralny-Wydział OrganizacyjnyReferat Sprawozdawczy, nr 1745/51 [31 V 1951]).

Informacja II. O działalności wroga (maszynopis), AAN (PZPR, Komitet Centralny-Wydział OrganizacyjnyReferat Sprawozdawczy, nr 1801/51 [4 VI 1957]).

Informacja III. Informacja o nastrojach $w$ zwiazku z wymianq odcinków nadgranicznych (maszynopis), AAN (PZPR, Komitet Centralny-Wydział OrganizacyjnyReferat Sprawozdawczy, nr 1719/51 [26 V 1951]).

Notatka służbowa 1952. Notatka służbowa z zebrania Komisji Naukowej przy Kierownictwie Badań Grodów Czerwieńskich, w dn. 28.VIII.52 w Hrubieszowie, o godz. 21-ej; maszynopis w archiwum Muzeum Zamojskiego w Zamościu.

Podkowińska, pismo 1946. Z. Podkowińska, pismo do Powiatowego Urzędu Ziemskiego w Tomaszowie Lubelskim z 24-go VII 1946; maszynopis w archiwum PMA, Warszawa, nr 353/46/MD.

Rajewski, zezwolenie 1949. Z. Rajewski, pismo do Ministerstwa Bezpieczeństwa Publicznego z 24-go VIII 1949 w sprawie zezwolenia na prace w pasie pogranicznym; maszynopis w archiwum PMA, Warszawa, nr L.dz. 523/XVIf/49.

Reinerth, szkic listu 1946. H. Reinerth, szkic listu do W. Antoniewicza z 29-go XI 1946; rękopis w Pfahlbaumuseum Unteruhldingen, Niemcy.

Wartołowska, list 1940. Z. Wartołowska, list do W. Antoniewicza z 7-go VII 1940; rękopis w Archiwum PAN, 
Warszawa, Materiały W. Antoniewicza, sygnatura III.22.

Wartołowska, list 1941. Z. Wartołowska, list do W. Antoniewicza z 7-go VII 1940; rękopis w Archiwum PAN, Warszawa, Materiały W. Antoniewicza, sygnatura III.22.

Wartołowska, sprawozdanie 1945. Z. Wartołowska, Sprawozdanie z prac wykopaliskowych na grodzisku we wsi Sasiadka w pow. Zamojskim w czasie od 28 VIII do 31 IX 1945; rękopis w archiwum PMA, Warszawa.

Zapiska, 1940.Докладнаязаписка Обохранеиоргаизации иследовании археологическихпамятниковзападной Украинь и западной Белоруссии; maszynopis w Instytucie Historii Kultury Materialnej Rosyjskiej Akademii Nauk, St. Petesburg.

\section{Opracowania}

Abramowicz A. 1991. Historia archeologii polskiej XIX i XX wieku. Warszawa-Łódź.

Abramowicz A. 2005. rec. B. Noszczak, 'Sacrum' czy ‘profanum'? Spór o istotę obchodów milenium polskiego (1949-1966), Towarzystwo Naukowe Warszawskie, Instytut Pamięci Narodowej. Komisja Ścigania Zbrodni przeciw Narodowi Polskiemu, Warszawa 2002, 269 ss., indeks osobowy. Archeologia Polski 50, 194-201.

Abramowicz A. 2010. Koral pamięci. Wspomnienia, pamiętniki, dzienniki, notatki i listy archeologa. Łódź, t. II. Wiek dojrzaty. Pod znakiem topaty.

Adamski Ł. 2011. Nacjonalista postępowy. Mychajło Hruszewski i jego poglady na Polskę i Polaków. Warszawa.

Antoniewicz W. 1953. Dotychczasowy dorobek archeologii Polski. Zapiski Archeologiczne 4. Warszawa.

Antoniewicz W., Wartołowska Z. (red.) 1964. Mapa grodzisk w Polsce. Wrocław-Warszawa-Kraków.

Bagińska J., Piotrowski M., Wołoszyn M. (red.) 2012. Czerwień - gród między Wschodem a Zachodem. Katalog wystawy = Červen' - eine Burg zwischen Ost und West. Ausstellungskatalog $=$ Cerven - un castrum tra Oriente e Occidente. Catalogo della mostra = Червень град між Сходом і Заходом. Каталог виставки. Tomaszów Lubelski-Leipzig-Lublin-Rzeszów.

Bartoszewicz H. 1995. Polsko-sowiecka umowa graniczna z 16 sierpnia 1945 roku. (W:) Polska i kraje Europy Środkowo-Wschodniej XIX-XX wiek. Studia ofiarowane Piotrowi Łossowskiemu w siedemdziesiata rocznice urodzin. Warszawa, 393-403.

Behrends J.C. 2006. Die erfundene Freundschaft. Propaganda für die Sowjetunion in Polen und in der DDR. Zeithistorische Studien 32. Köln-Weimar-Wien.
Berger S. 2015. The Past as History. National Identity and Historical Consciousness in Modern Europe. Basingstoke.

Błachowska K. 2005. Dzieje Rusi w badaniach historyków lwowskich dwudziestolecia międzywojennego. (W:) J. Maternicki, L. Zaszkilniak (red.), Wielokulturowe środowisko historyczne Lwowa w XIX i XX w. Rzeszów, t. III, 380-391.

Brzostowicz M. 2014. Osiągnięcia Józefa Kostrzewskiego w badaniach nad wczesnym średniowieczem w Polsce. Fontes Archaeologici Posnanienses 50:1, 89-100.

Buko A. 2011. Archeologia Polski wczesnośredniowiecznej. Odkrycia - hipotezy-interpretacje. Warszawa.

Buko A. 2014. Czy Józef Kostrzewski był badaczem wczesnego średniowiecza? Fontes Archaeologici Posnanienses 50:1, 101-110.

Buko A., Gołub St. (red.) 2016. Od cerkwi katedralnej króla Daniela Romanowicza do bazyliki pw. Narodzenia NMP $w$ Chetmie. Wyniki badań interdyscyplinarnych sezonu 2013-2014. Chełm.

Chochorowski J. 2016. Tadeusz Sulimirski (1898-1983) patriota i uczony. (W:) B. Chudzińska, M. Wojenka, M. Wołoszyn (red.), Od Bachórza do Światowida ze Zbrucza. Tworzenie się słowiańskiej Europy w ujęciu źródłoznawczym. Księga jubileuszowa Profesora Michała Parczewskiego. Kraków-Rzeszów, 783-806.

Czopek S., Parczewski M. (red.) 1996. Poczqtki sqsiedztwa. Pogranicze etniczne polsko-rusko-słowackie w średniowieczu. Rzeszów.

Czykałenko = Чикаленко Л. 1998. Справоздання з розкопок в околицях стародавнього Червна влітку 1940 року. Записки Наукового Товариства імені Шевченка 235, 623-635.

Dąbrowska E. 2016. Wspomnienie o profesorze Aleksandrze Gieysztorze. (W:) M. Koczerska, P. Węcowski (red.), Aleksander Gieysztor. Człowiek $i$ dzieło. Warszawa, 183-186.

Dąbrowska M. (red.) 2012. Oskar Halecki i jego wizja Europy. Warszawa-Łódź, t. I.

Dąbrowska M. (red.) 2014a. Oskar Halecki i jego wizja Europy. Warszawa-Łódź, t. II.

Dąbrowska M. (red.) 2014b. Oskar Halecki i jego wizja Europy. Warszawa-Łódź, t. III.

Diensttagebuch... 1975. Das Diensttagebuch des deutschen Generalgouverneurs in Polen 1939-1945. W. Präg, W. Jacobmeyer (red.), Quellen und Darstellungen zur Zeitgeschichte 20. Stuttgart.

Dmitrów E. 2009. Zwischen Mythos und Geschichte: Die Formierung des kollektiven Gedächtnisses in Polen nach dem Zweiten Weltkrieg. (W:) E. Dmitrów, T. Weger (red.), Deutschlands östliche Nachbarscha- 
ften. Eine Sammlung von historischen Essays für Hans Henning Hahn. Die Deutschen und das östliche Europa. Studien und Quellen 4. Frankfurt am Main-BerlinBern-Bruxelles-New York-Oxford-Wien, 175-208.

Drewko M. 1957. Sprawozdania z badań przeprowadzonych w 1955 r. na wczesnośredniowiecznym cmentarzysku kurhanowym we wsi Lipsko, pow. zamojski. Sprawozdania Archeologiczne 3, 165-167.

Dunin-Wąsowicz T. 2000. Głos w dyskusji. (W:) H. Samsonowicz (red.), Ziemie polskie $w X$ wieku i ich znaczenie $w$ ksztattowaniu się nowej mapy Europy. Kraków, 251-253.

Dunin-Wąsowicz T. 2011. Drogami średniowiecznej Polski: studia z dziejów osadnictwa i kultury. A. Janeczek, M. Młynarska-Kaletynowa (red.). Warszawa.

Durczewski Z. 1939. Stary Zamek w Grodnie w świetle wykopalisk dokonanych $w$ latach 1937-1938. Grodno.

Dwie nowe... 1936. Dwie nowe placówki kulturalne m. Lwowa. Gazeta Lwowska rok 129 (2 XII 1936), 2.

Eckert E. 2012. Zwischen Ostforschung und Osteuropahistorie. Zur Biographie des Historikers Gotthold Rhode (1916-1990). Einzelveröffentlichungen des Deutschen Historischen Instituts Warschau 27. Osnabrück.

Evans R.J.W., Marchal G.P. (red.) 2011. The uses of the middle Ages in modern European states. History, Nationhood and the Search for Origins. Basingstoke.

Fedoriszczak = Федорищак Р.Л. 2013. Педагогічна діяльність Мірона Кордуби в роки другої світової війни та повоєнної відбудови. Наукові записки. Серія: Педагогіка 1, 3-8.

Florek M., Wołoszyn M. (red.) 2016. The early medieval settlement complex at Czermno in the light of results from past research (up to 2010). Material evidence = Wczesnośredniowieczny zespół osadniczy w Czermnie $w$ świetle wyników badań dawnych (do 2010). Podstawy źródłowe, U Źródeł Europy Środkowowschodniej / Frühzeit Ostmitteleuropas 2. Kraków-LeipzigRzeszów-Warszawa, t. I-II.

Franaszek A. 2011. Miłosz. Biografia. Kraków.

Gieysztor A. 1953. Prace badawcze na obszarze Grodów Czerwieńskich. Kwartalnik Historyczny 60, 302-316.

Golczewski F. 2010. Deutsche und Ukrainer 1914-1939. Paderborn-München-Wien-Zürich.

Golczewski F. 2017. Die deutsch geförderte Ukrainisierung der polnischen Ortodoxie 1939-1941. (W:) M. Thomsen (red.), Religionsgeschichtliche Studien zum östlichen Europa. Festschrift für Ludwig Steindorff zum 65. Geburtstag. Quellen und Studien zur Geschichte des östlichen Europa 85. Stuttgart, 281-306.

Gorskaja = Горская Н.А. 1999. Борис Дмитриевич Греков. Москва.
Grala H. 2016. 'Nasz dorogij Aleksandr Sanycz'. Aleksander Gieysztor i 'przyjaciele Moskale'. (W:) M. Koczerska, P. Węcowski (red.), Aleksander Gieysztor. Człowiek i dzieło. Warszawa, 31-50.

Grekow = Греков Б.Д. 1939. Древнейшие судьбы Западной Украины. Новый мир 10-11, 248-256.

Grelka F. 2005. Die ukrainische Nationalbewegung: unter deutscher Besatzungsherrschaft 1918 und 1941/42. Studien der Forschungsstelle Ostmitteleuropa an der Universität Dortmund 38. Wiesbaden.

Gurba J., Urbański A. 1998. Nowe materiały do datowania drewnianych konstrukcji zespołu grodowego 'Czerwień’ w Czermnie nad Huczwą. Archeologia Polski Środkowo-Wschodniej 3, 159-165.

Hensel W. 1946. Potrzeba przygotowania wielkiej rocznicy. Poznań.

Hryciuk G. 2009. Die Illusion der Freiheit. Die sowjetische Besatzung Ostpolens. Osteuropa 59:7-8, 173-186.

Jakimowicz R. 1933. Szlak wyprawy kijowskiej Bolesława Chrobrego $w$ świetle archeologji (próba ujęcia zagadnień wczesnohistorycznych Wotynia). Równe.

Janeczek A. 2013. Ruś Czerwona - perypetie z nazwą. (W:) V. Nagirnyy (red.), Ruś w epoce najazdów mongolskich. Colloquia Russica I.3. Kraków, 227-229.

Janeczek A. 2016. The landscape of the region around Cherven'-Czermno in the Late Medieval and the Early Modern Period $=$ Krajobraz okolic CzerwieniaCzermna w późnym średniowieczu i wczesnej nowożytności. (W:) Florek, Wołoszyn (red.), t. I, 141-194.

Jarosz D. 1993. Pogłoski jako wyraz świadomości potocznej chłopów w Polsce w 1. 1949-56. Dzieje Najnowsze 25:3, 39-55.

Jasienica P. 1952. Wykopaliska. Przekrój 389 (21-ty IX 1952), 9.

Jażdżewski K. 1959. Ogólne wiadomości o Czermnie - Czerwieniu. Archeologia Polski 4, 67-91.

Jażdżewski K. 1995. Pamiętniki. Wspomnienia polskiego archeologa $z X X$ wieku. Łódź.

Kalaga J. 2013. Historia i stan badań. (W:) Kalaga [red.] 2013, 17-19.

Kalaga J. (red.) 2013. Sutiejsk. Gród pogranicza polsko-ruskiego w X-XIII w. Studium interdyscyplinarne. Warszawa-Pękowice.

Kobyliński Z., Rutkowska G. 2005. Propagandist use of history and archaeology in justification of Polish rights to the 'Recovered Territories' after World War II. Archaeologia Polona 43, 51-124.

Kobyliński Z. 2007. Archeologia wczesnego średniowiecza w Polsce 1939-1989: sukcesy i porażki. (W:) J. Lech (red.), Pół wieku z dziejów archeologii pol- 
skiej (1939-1989), Komitet Nauk Pra- i Protohistorycznych. Prace 6. Warszawa, 357-410.

Kokowski A., Łuczkiewicz P. 2016. Dzieje archeologii w Uniwersytecie Marii Curie Skłodowskiej w Lublinie. (W:) M. Rybicka, M. Rzucek (red.), Nasi Mistrzowie. Rzeszów, 109-130.

Kostrzewski J. 1947. Kultura prapolska. Prace Instytutu Zachodniego 11. Poznań.

Kowalczyk E. 2000a. Profesor Aleksander Gieysztor - przyjaciel archeologii i archeologów. Przeglą Historyczny 91, 69-76.

Kowalczyk E. 2000b. Momenty geograficzne państwa Bolesława Chrobrego. Na styku historii i archeologii. Kwartalnik Historyczny 57, 41-76.

Kozak S. 2008. Ukraiński Instytut Naukowy w Warszawie (1930-1939). Warszawskie Zeszyty Ukrainoznawcze 25-26, 15-22.

Kozłowski M. 2014. Oskar Halecki i jego uczniowie. Wzajemne relacje po latach. (W:) Dąbrowska [red.] 2014b, 24-77.

Kozłowski S.K. 2009a. Włodzimierz Antoniewicz. Profesor z Warszawy. Warszawa.

Kozłowski S.K. 2009b. Zdrajcy, czy bohaterowie?... Polska archeologia kolejnych niemieckich okupacji. (W:) H. Taras, A. Zakościelna (red.), Hereditas praeteriti. Additamenta archaeologica et historica dedicata Ioanni Gurba Octogesimo Anno Nascendi. Lublin, 69-83.

Kozłowski S.K. 2010. Respons Profesorowi. Przeglad Archeologiczny 58, 171-173.

Kozłowski S.K. 2012. Archeologiczne królestwo Wernera Radiga w Generalnym Gubernatorstwie. Kraków.

Kozłowski S.K. 2013. Polscy Ukraińcy i ukraińscy Polacy w lwowskiej archeologii lat 1905-1945. Przeglad Archeologiczny 61, 233-241.

Kozłowski S.K. 2014. Archeologii wczesnodziejowej polskie początki. Fontes Archaeologici Posnanienses 50:1, 199-203.

Kozłowski S.K., Sytnyk O. = Козловский С.К., Ситник О. (red.) 2010. Profesor Leon Kozłowski = Професор Леон Козловський. Lwów-Warszawa = ЛьвівВаршава.

Kubijowicz = Кубійович В. 1975 Українці в Генеральній Губерні 1939-1941. Історія Украӥнського Центрального комітету. Чікаго.

Kuczyński S.M. 1965. O wyprawie Włodzimierza I ku Lachom na podstawie wzmianki z r. 981 w Opowieści lat doczesnych. (W:) S.M. Kuczyński, Studia z dziejów Europy Wschodniej X-XVII w. Warszawa, 33-118.

Kurnatowska Z. (Hilczerówna Z.) 2000. Badania nad początkami i rozwojem społeczeństwa wczesnopolskiego. (W:) M. Kobusiewicz, S. Kurnatowski (red.), Ar- cheologia i prahistoria polska w ostatnim półwieczu. Materiały z Konferencji Dorobek polskiej archeologii i prahistorii ostatniego pótwiecza w Puszczykowie koto Poznania (27 - 30 października 1997 r.). Poznańskie Towarzystwo Przyjaciół Nauk. Prace Komisji Archeologicznej 20. Poznań, 381-412.

Kuśnierz J. 2003. Historia i stan badań latopisowych grodów Czerwień i Wołyń oraz ich okolic. Zamojsko-Wotyńskie Zeszyty Muzealne 1, 6-22.

Lech J. 1997-1998. Between captivity and freedom: Polish archaeology in the $20^{\text {th }}$ century. Archaeologia Polona 35-36, 25-222.

Lech J. 2006. Z badań polsko-ukraińskich związków w archeologii do II wojny światowej. Przeglad Archeologiczny 54, 5-59.

Lech J. 2009. O genezie i wczesnych dziejach Instytutu Historii Kultury Materialnej PAN wraz z uwagami do artykułu 'Imperium atakuje', pióra Prof. Stefana K. Kozłowskiego. Przeglad Archeologiczny 57, 191-214.

Lech J. 2010. Responsibility i badania historii archeologii w XX wieku. Przeglad Archeologiczny 58, 175-186.

Losy cerkwi... 1997 Losy cerkwi w Polsce po 1944 roku. Rzeszów.

Lozny L.R. (red.) 2017. Archaeology of the Communist Era: A Political History of Archaeology of the $20^{\text {th }}$ Century. Cham.

Łowmiański H. 1953. Problematyka historyczna Grodów Czerwieńskich w związku z planem zespołowych badań polsko-radzieckich. Kwartalnik Historyczny 60, 58-85.

Maleczyński K., Mańkowski T., Pohorecki F., Tyrowicz M. 1939. Lwów i ziemia czerwieńska. Lwów.

Markiewicz P. 2016. Volodymir Kubijovych's Ethnographic Ukraine: Theory into Practice on the Western Okraiiny. Jahrbuch für Geschichte Osteuropas 64:2, 228-259.

Maternicki J., Zaszkilniak L. (red.) 2007. Złota księga historiografii lwowskiej XIX i XX wieku. Rzeszów, t. I.

Maternicki J., Sierżęga P., Zaszkilniak L. (red.) 2014. Złota księga historiografii lwowskiej XIX i XX wieku. Rzeszów, t. II.

Matwijów M. 1996. Walka o lwowskie dobra kultury w latach 1945-1948. Wrocław.

Matwijowski K.J. 2016. Lwowscy historycy współtwórcami wrocławskiego ośrodka badań historycznych. (W:) F. Wolański, L. Ziatkowski (red.), W kręgu myśli Władysława Czaplińskiego. Wrocławskie Prace z Historii Nowożytnej 1. Wrocław, 15- 25.

Mędrzecki W. 2010. Język dialogu historyków polskich i ukraińskich na przełomie XX i XXI wieku. (W:) 
M. Zowczak (red.), Na pograniczu 'nowej Europy'.

Polsko-ukraińskie sqsiedztwo. Warszawa, 45-52.

Miłosz Cz. 1959. Rodzinna Europa. Paryż.

Miłosz Cz. 2007. Zaraz po wojnie. Korespondencja z pisarzami 1945-1950. Kraków.

Motyka M. 2011. Od rzezi wotyńskiej do akcji „Wisła”. Konflikt polsko-ukraiński 1943-1947. Kraków.

Musianowicz K. 1979. Zespół osadniczy z Gorodka obwód roweński (USRR) w świetle wczesnośredniowiecznego osadnictwa Wołynia. Wiadomości Archeologiczne $44: 2,168-205$.

Neighbours... 2004. Archaeologia Polona 42 (Neighbours: Polish-German relations in archaeology. Part 1 - to 1945).

Neighbours... 2005. Archaeologia Polona 43 (Neighbours: Polish-German relations in archaeology. Part 2 - after 1945).

Noszczak B. 2002. 'Sacrum' czy 'profanum'? Spór o istote obchodów milenium polskiego (1949-1966). Warszawa.

Nowakowski A. 1972. Górne Pobuże w wiekach VIII-XI. Zagadnienia kultury. Łódź.

Otwock... 1953. Otwock, 1951-52. Pierwsza Konferencja Metodologiczna Historyków Polskich. Przemówienia, Referaty, Dyskusja, St. Herbst, W. Kula, T. Manteuffel, J. Sieradzki, Z. Mianowska (red.). Warszawa, t. I-II.

Parczewski M. 1991. Poczatki ksztattowania się polsko-ruskiej rubieży etnicznej w Karpatach. U źródeł rozpadu Słowiańszczyzny na odłam wschodni i zachodni. Kraków.

Pasternak J. (Пастерна́к Я.I.) 1938. Katedra halicka w Kryłosie. Biuletyn Historii Sztuki i Kultury 6:1, 57-65.

Pasternak J. (Пастерна́к Я.І.) 1961. Археологія України: первісна, давня та середня історія Украӥни за археологічними джерелами. Торонто.

Petehyrycz W., Fyłypczuk M. 1998. Pierwszy badacz latopisowego Czerwienia - w 110 rocznicę urodzin. Archeologia Polski Środkowowschodniej 3, 313-314.

Piotrowska D. 2006. Z działalności instytucji II Rzeczpospolitej chroniących zabytki archeologiczne na zachodniej Ukrainie. Przeglad Archeologiczny 54, 61-98

Piotrowska D. 2007. Państwowe Muzeum Archeologiczne w Warszawie w latach 1939-1989. (W:) J. Lech (red.), Pół wieku z dziejów archeologii polskiej (1939-1989). Komitet Nauk Pra- i Protohistorycznych. Prace 6. Warszawa, 27-102.

Piskorski J.M., Hackmann J., Jaworski R. (red.) 2002. Deutsche Ostforschung und polnische Westforschung im Spannungsfeld von Wissenschaft und Politik. Disziplinen im Vergleich. Deutsche Ostforschung und polnische Westforschung 1. Osnabrück-Poznań.
Poleski J. 2004. Wczesnośredniowieczne grody $w$ dorzeczu Dunajca. Kraków.

Poleski J. 2017. Kontakty plemion zamieszkujących tereny Polski z państwem morawskim i państwem czeskim w IX i X wieku a problem kształtowania się państwa pierwszych Piastów. (W:) W. Drelicharz, D. Jasiak, J. Poleski (red.), Spór o poczatki Państwa Polskiego. Historiografia, tradycja, mit, propaganda. Kraków, 49-98.

Pomian K. 2002. Archeologia, historia, naród. (W:) B. Wawrzykowska (red.), Archeologia toruńska. Historia i teraźniejszość. Materiały z konferencji naukowej zorganizowanej z okazji 140-lecia muzealnych zbiorów archeologicznych w Toruniu. Toruń 16-17 maja 2002. Toruń, 9-15.

Poppe A. 1958. Gród Wołyń. Z zagadnień osadnictwa wczesnośredniowiecznego na pograniczu polsko-ruskim. Studia Wczesnośredniowieczne 4, 227-300.

Ratycz = Ратич O.O. 1959. Древньоруські вироби з кості i рогу, знайдені на территоріі Галицькоі і Волиньскоі земель. Материалі і дослідження з археологіi Прикарпаття і Волині 2, 119-131.

Rhode G. 1955. Die Ostgrenze Polens. Politische Entwicklung, kulturelle Bedeutung und geistige Auswirkung. Köln-Graz 1955, t. I. Im Mittelalter bis zum Jahre 1401.

Reichenbach K. 2016. Millionen für's Millenium. Finanzierung und Ausstattung der Forschungen zu den Anfängen des polnischen Staates 1949-1953. (W:) S. Grunwald, U. Halle, D. Mahsarski, K. Reichenbach (red.), Die Spur des Geldes. Mäzene, Förderer und Förderstrukturen der Prähistorischen Archäologie. Bielefeld, 259-280.

Romek Z. 2002. Nauka przeciw ideologii. Współpraca historyków polskich i radzieckich po II wojnie światowej. Dzieje Najnowsze 34:1, 95-102.

Romek Z. 2010. Cenzura a nauka historyczna w Polsce 1944-1970. Warszawa.

Rotfeld A.D., Torkunow A.W. (red.) 2010. Białe plamy - czarne plamy. Sprawy trudne w polsko-rosyjskich stosunkach 1918-2008. Warszawa.

Rutkowski T.P. 2013. Różne barwy przystosowania. Wokół działalności Aleksandra Gieysztora w PRL. Annales Universitatis Paedagogicae Cracoviensis. Studia Politologica 9, 138-156.

Sierżęga P. 2011. Kazimierz Tyszkowski (1894-1940). Z dziejów nauki polskiej w międzywojennym Lwowie. Rzeszów.

Sikora P., Wołoszyn M. 2011. 981 - Volodímer zog zu den Ljachen und nahm ihre Städte: Peremyšl', Červen und die anderen Städte. Forschungsgeschichte und neuere 
Untersuchungen zu den Červenischen Burgen. (W:) F. Biermann, Th. Kersting, A. Klammt (red.), Der Wandel um 1000. 18. Jahrestagung des Mittel-und Ostdeutschen Verbandes für Altertumsforschung in Greifswald 2009, 23. bis 27. März 2009. Beiträge zur Ur- und Frühgeschichte Mitteleuropas 60. Langenweissbach, 233-248.

Smoleń M. 2004. Wymiana terytoriów między Polską a ZSRR w 1951 r. (W:) J. Diec, A. Tyszkiewicz (red.), Zwiazek Radziecki wobec krajów Europy Środkowej i Wschodniej 1920-1991. Kraków, 85-101.

Sowa A.L. 1998. Stosunki polsko-ukraińskie 1939-1947. Kraków.

Stobiecki R. 1997. Pierwsza konferencja metodologiczna historyków polskich. (W:) R. Bäcker, P. Hübner (red.), Skryte oblicze systemu komunistycznego. U źródet zła... Warszawa, 193-210.

Stryjek T. 2002. Historiografia a konflikt o Kresy Wschodnie w latach 1939-1953. Radzieckie, rosyjskie, ukraińskie i polskie prezentacje dziejów ziem wschodnich dawnej Rzeczypospolitej jako część 'wojny ideologicznej’ w okresie lat trzydziestych-pięćdziesiątych. (W:) K. Jasiewicz (red.), Tygiel narodów. Stosunki spoleczne i etniczne na dawnych ziemiach wschodnich Rzeczypospolitej 1939-1953. Warszawa, 429-564.

Sytnyk O. 2006. Katedra archeologii Uniwersytetu Lwowskiego w latach 1905-2005. Przeglad Archeologiczny 54, 125-159.

Szumski J. 2016. Polityka a historia. ZSRR wobec nauki historycznej w Polsce w latach 1945-1964. Warszawa.

Świstowski F. 2009. Niemieckie i ukraińskie szkolnictwo w powiecie chełmskim w okresie okupacji 1939-1944. Zarys problematyki. Rocznik chetmski 13, 321-328

Tabaczyńscy E. i S. 2005. Sacrum czy profanum? Uwagi na marginesie pracy B. Noszczaka (2002) oraz recenzji A. Abramowicza (2005). Archeologia Polski 50, 134-144.

Tebinka J. 1994. Proponowana zmiana polskiej granicy wschodniej w 1952 r. Dzieje Najnowsze 3, 71-75.

Tyszkiewicz J. 2004. The Oldest Border of the Piast State - an attempted Summary. Questiones Medii Aevi Novae 9, 183-204.

Tyszkiewicz J. 2008. Uwagi o działalności politycznej St. Zakrzewskiego. (W:) J. Pisulińska, P. Sierżęga, L. Zaszkilniak (red.), Historia-Mentalność-Tożsamość. Miejsce i rola historii oraz historyków w życiu narodu polskiego i ukraińskiego $w$ XIX i XX wieku. Rzeszów, 459-470.

Wartołowska Z. 1958. Gród Czerwieński Sutiejsk na pograniczu polsko-ruskim. Światowit 22, 7-137.
Wawryniuk A.A. 2015. Granica polsko-sowiecka po 1944 roku (na odcinku z Ukraina). Chełm.

Wołoszyn M. 2012. Die frühmittellaterlichen ortodoxen Devotionalien in Polen und die Entstehung der ältesten Ostgrenze Polens. Forschungsgeschichte und Forschungsperspektiven. (W:) M. Salamon, M. Wołoszyn, A. Musin, P. Špehar, M. Hardt, M. P. Kruk, A. Sulikowska-Gąska (red.), Rome, Constantinople and Newly-Converted Europe: Archaeological and Historical Evidence. U Źródeł Europy Środkowowschodniej / Frühzeit Ostmitteleuropas 1, 2. KrakówLeipzig-Rzeszów-Warszawa, t. II, 225-289.

Wołoszyn M. 2013. Grody Czerwieńskie i problem wschodniej granicy monarchii pierwszych Piastów. Stan i perspektywy badań. Studia nad dawna Polska 3, 87-118.

Wołoszyn M. 2016a. Cherven' Town that is the golden apple of Polish archaeology... Assumptions and implementation of an international research project $=$ Grody Czerwieńskie czyli złote jabłko polskiej archeologii... Założenia i realizacja międzynarodowego projektu badawczego. (W:) Florek, Wołoszyn (red.). t. I, 13-51.

Wołoszyn M. 2016b. The archaeological fieldwork in Czermno in 1940 = Badania archeologiczne w Czermnie w 1940 r. (W:) Florek, Wołoszyn (red.). t. I, 197218.

Wołoszyn M. w druku. Wie betreibt man Archäologie in einem Land, in dem es nur um, warmes Wasser aus dem Wasserhahn' geht? Zur frühgeschichtlichen Archäologie in Polen nach der Wende. (W:) J. Drauschke, R. Prien (red.), Quo Vadis Frühgeschichtliche Archäologie? Studien zu Spätantike und Frühmittelalter 9. Hamburg.

Wołoszyn M. (red.) w przygotowaniu. From Cherven' Towns to Curzon Line. The lands on the Middle Bug during the Middle Ages and the historiographic perspective on the formation of Poland's eastern border, $18^{\text {th }}-21^{\text {st }}$ centuries $=$ Od Grodów Czerwieńskich do linii Curzona. Dzieje środkowego Pobuża $w$ wiekach średnich oraz postrzeganie formowania się wschodniej granicy Polski w historiografii XVIII-XXI w. U Źródeł Europy Środkowowschodniej / Frühzeit Ostmitteleuropas 3, Kraków-Leipzig-Rzeszów-Warszawa.

Wood I. 2013. The Modern Origins of the Early Middle Ages. Oxford.

Zarubij = Зарубій Е. 2009. Історія Відділу археології Львівського історичного музею. Наукові записки 13, 152-172.

Zemła M. 2011. Tygrys: gnoza polityczna. Postscriptum Polonistyczne 2 (8), 161-190. 


\section{RIGHT AFTER THE WAR: ON THE HISTORY OF STUDIES \\ ON THE POLISH-EARLY RUS' BORDERLAND CONDUCTED IN 1945-1956 (WITH EMPHASIS ON SO-CALLED CHERVEN'TOWNS)}

\section{SUMMARY}

In this article I would like to present some remarks on the history of studies on the Polish-early Rus' borderland, mainly studies on so-called Cherven' Towns, which were strongholds in Czermno and Gródek in eastern Poland. I concentrate on the post-war period (until 1956), but in order to present the events of that time in the proper context it is necessary to briefly go back in time to the Second Republic of Poland and the years 1939-1945.

For a very long time Polish archeology focused on prehistory and systematic studies on the Middle Ages did not start until the end of the interwar period, mainly in Greater Poland, where the early Piast strongholds in Gniezno, Kłeck and Poznań started to be examined in 1936-1939 (see Brzostowicz 2014; Buko 2014; Kozłowski 2014).

Studies on the archaeology of the Middle Ages in the eastern parts of the Second Republic of Poland (presentday parts of Lithuania, Belarus' and Ukraine) likewise remained in their early stages, but it should be emphasised that in the 1930s in Lwów (today L' viv) there was a considerable growth of interest in the Cherven' Land, including the archaeology of this region. In 1935 the journal Ziemia Czerwieńska (Cherven' Land) started to be published there, and the Museum of the Prehistory of the Cherven' Land was planned to be opened in Lwów/ L' viv in 1940. World War II thwarted those plans and goals.

After the outbreak of World War II the archaeological sites in Czermno and Gródek found themselves on the eastern borders of the General Government (see Wołoszyn 2012, Fig. 19). In the summer of 1940, during the German occupation, first excavation works were started in Czermno led by L. Chykalenko, a Ukrainian archaeologist. He carried out these works on the orders of the Ukrainian Central Committee, an organisation established in the spring of 1940 for the purpose of convincing the German authorities, including Hans Frank himself, to implement a pro-Ukrainian (and anti-Polish; see Markiewicz 2016) policy in the eastern part of the General Government.

It seems certain that the excavations in Czermno were carried out as part of the efforts aimed at awakening the 'Ukrainian national spirit'. What is more difficult to prove is that the German authorities were officially interested in them. It is obvious, however, that the Polish side was concerned about the works. This is clearly indicated by the letter sent by Z. Wartołowska to W. Antoniewicz, dated $1^{\text {st }}$ July 1940 (see Wartołowska, list 1940).
The post-war period brought about a number of changes in Polish archaeology, both related to its organisation and the subject of studies. Regarding the former, I am in particular referring to the establishment of large non-university research institutions, employing a considerable number of archaeologists; with regard to the latter I mean the dramatic increase in studies on the beginnings of the Polish state. Both these factors contributed to the fact that Polish archaeology of the Middle Ages changed from a marginal field to a very important, if not the most important, part of our discipline.

Even though formally the excavation works carried out at the time covered the territory of entire Poland, their centre of gravity was in the west, in Great Poland, Silesia and Pomerania. How did the question of studies on the Polish-early Rus' borderland look in this context?

The idea of excavations in Czermno and Gródek was born right after the war, originating with the State Archaeological Museum in Warsaw (see Podkowińska, pismo 1946; Rajewski, pozwolenie 1949).

What turned out to be a turning point, though, was the so-called methodological conference in Otwock (28 December 1951-12 January 1952) - a meeting which was to facilitate a Marxist transformation of Polish historical science (see Stobiecki 1997). It was also attended by representatives from the USSR, such as B. Rybakov. As the conference documents, discovered in the Museum of Zamość by J. Kuśnierz, show, it was then that the idea of Polish-Soviet cooperation on Cherven' Towns was formulated.

Already in 1952 excavations began in the strongholds in Czermno (one season only - 1952), Gródek (1952-1955), and the early Slavonic burial ground in Lipsk (1952-1955). At the same time excavations were also carried out in the gord in Sąsiadka (1952-1955).

These investigations were often described as PolishSoviet, but in fact the participation of archaeologists from the USSR was minimal and limited to courtesy visits such as the one paid by A. W. Arcichovsky in 1953.

The excavation of Cherven' Towns, started under the banner of Polish-Soviet cooperation and generously funded by the Polish government, were stopped quite abruptly. For many years the reasons for this decision aroused interest, especially since one of the participants in the excavations at the time, A. Abramowicz $(1991,159)$, recalled that they 
were supposedly related to the adjustment of the border between the Polish People's Republic and the USSR.

In 1951 there was a 'voluntary' territorial exchange between the Polish People's Republic and the USSR; in the second half of 1952 the Soviet authorities turned to Poland with the proposal to take over more powiats (counties) of eastern Poland. If the second agreement had been implemented, Gródek would have found itself on the Soviet side of the border, and the stronghold in Czermno would have been situated very near the border. This proposal was probably not carried out because of Stalin's death ( $5^{\text {th }}$ March 1953; Tebinka 1994; Wawrzyniak 2015).

In this article I try to show that it is not possible to connect these events to the excavations on the Bug River. The 'voluntary' exchange with the USSR of the border territories in 1951 was compromising enough for the Polish Communist authorities not to make the Big Brother's next proposal widely known.

In order to fully explain the reasons why the campaign of excavating Cherven' Towns came to a halt in the 1950 s, it will be necessary to conduct further archive research. However, it is possible to identify a number of more general factors which were not conducive to carrying out such works, for instance the hostile attitude of the Polish society (including scholars) towards the USSR and, most importantly, the imposed cooperation with the Big Brother (Jażdżewski 1995, 266-267). We must mention the considerable formalisation (ritualisation) of contacts with Soviet representatives, and the unbearable corset of Soviet political control (see Romek 2002; Szumski 2016, 332). It is also worth noting that for the legitimisation of the Polish People's Republic's authorities it was important to emphasise not only fixing Poland's western border on the Oder and Nysa Rivers, but also the benefits of losing the so-called Kresy (Eastern Borderlands). The propaganda machine of the Polish People's Republic spared no expense to justify our 'ancient' rights to Szczecin or Wrocław (Kobyliński, Rutkowska 2005; Dmitrów 2009). The eastern border of the Polish People's Republic was equally as correct, allegedly established along the fair Curzon Line. Recalling the significance of Polish culture for the territories east of this line was not a preferred subject of studies. At the same time, and this is the most important point in our estimation, speaking about Orthodox and early Rus' or Ruthenian elements in the eastern part of present-day Poland did not agree with the vision of the Polish People's Republic luckily saved by Stalin and Polish Communists from the nightmare of ethnic or religious minorities.

In a long-term perspective, however, what seems crucial are civilisation changes in the aftermath of World War II. From 1945 onwards, as a result of losing Lwów/L'viv and Wilno/Vilnius, there were no large research centres or museums in Poland east of the Vistula River.

After the termination of the excavations in the $1950 \mathrm{~s}$ no larger plans of archaeological investigations on the Polish-early Rus' borderland were formulated in the Polish People's Republic. In 1976-1979 there were large-scale excavations in Czermno, led by J. Gurba. The course of this team's work, the manner in which the features and artefacts were treated, and the lack of source-books are all sad evidence of the logistical shortages suffered by the institution which made this attempt.

The collapse of totalitarian systems in our part of Europe marks an obvious turning point also in the history of Polish archaeology, including studies on eastern Poland (see Wołoszyn, in press).

Gradually, studies on the Polish-early Rus' borderland started to accelerate. We must not forget the work of M. Parczewski on the beginnings of the Polish Rus'ian borderland (Parczewski 1991). In the mid-1990s, owing to the efforts of A. Buko, an international and interdisciplinary team started to form, for the purpose of conducting a comprehensive investigation of Chełm and nearby Stołpie (see recently Buko, Gołub [ed.] 2016).

A Polish-German team working on Cherven' Towns has been developing since 2008. At present, a few dozen people are involved in studying the region; the work of our team is financed by Polish and German funds, and researchers from Poland, Germany, Russia, Serbia, Switzerland and Ukraine participate in the project (see Wołoszyn 2016b).

To conclude the above essay, I would like to express a strong conviction that both Czermno and Gródek will provide many more fantastic features and artefacts connected with the formation of the Polish-early Rus' borderland, and a hope that the efforts of the international interdisciplinary team, which I am honoured to lead, will make Cherven' Towns an important point on the map of contemporary European medieval studies. 
Adres Autora:

Dr hab. Marcin Wołoszyn, prof. UR

Instytut Archeologii Uniwersytetu Rzeszowskiego

ul. Moniuszki 10

35-015 Rzeszów

Polska

Instytut im. Leibniza Historii i Kultury

Europy Wschodniej (GWZO)

Reichsstr. 4-6

04-109 Lepzig

Niemcy

e-mail: marcinwoloszyn@gmail.com 